\title{
Financial-real side interactions in an extended Monetary Circuit with shadow banking: Loving or Dangerous Hugs?
}

\author{
Alberto Botta*, Eugenio Caverzasi and Daniele Tori ${ }^{\dagger \neq}$ \\ Mediterranean University of Reggio Calabria \\ Marche Polytechnic University \\ University of Greenwich
}

"The typical macro treatment of finance
was a set of arbitrage equations, under
the assumption that we did not need to
look at who was doing what on Wall
Street. That turned out to be badly
wrong"
(Blanchard, IMF Survey Magazine,
Interview With Olivier Blanchard:

31, 2015.)

\begin{abstract}
Monetary circuit theory is one of the most interesting attempts to formally describe the functioning of a monetary production economy as centered around the concept of flux-reflux of money. Endogenous money creation by commercial banks allows the circuit to open and firms to implement production processes. Financial markets "passively" close the circuit by intermediating savings via bond and equity issuance. Despite its natural focus on financial-real side links, the monetary circuit literature has paid relatively little attention to 'financialization' and the way it has modified real-financial dynamics. In this paper, we analyze whether the flux-reflux perspective of the circuit may be fruitfully applied to the description of the linkages between the real economy and finance in a financialized economy. We propose two interconnected circuits, one for the real economy and one for the financial one. In this context, finance can still ensure a consistent closure of the whole system, thus directly allowing the functioning of the real economy. Newly developed inside-finance interactions, however, may indirectly influence real world dynamics by easing/restricting access to credit/financial markets and give rise to boom-and-bust cycles. Our aim is twofold: modeling modern financial worlds within a MC framework and understanding how financialization could have changed real-financial interactions.
\end{abstract}

Keywords monetary circuit theory; financialization; shadow banking

\footnotetext{
* Corresponding author: abotta@eco.unipv.it

${ }^{\dagger}$ Alberto Botta is Assistant Professor, Department of Law and Economics, Mediterranean University of Reggio Calabria. Eugenio Caverzasi is a post-doc fellow, Department of Economics and Social Sciences, Marche Polytechnics University. Daniele Tori is a Ph.D candidate, Department of International Business and Economics, University of Greenwich.

₹ The authors thank Guglielmo Forges Davanzati and anonymous referees for their insightful comments and questions. We are also grateful to Clara Capelli for her participation in the first stage of this study and for her helpful suggestions.
} 


\section{Introduction}

Monetary Circuit Theory (henceforth MCT) clearly stands out as one of the most rigorous attempts to describe the functioning of a monetary economy of production. In doing so, MCT casts light on the fundamental links between finance and the real side of the economy in order to allow production and consumption decisions to take place. Production processes can take place thanks to bank money creation by commercial banks that endogenously provide firms with new purchasing power in order to allow them to cover production costs. Newly created money first moves from firms to households in the form of wage payments. Money refluxes back to firms due to household consumption expenditure. This allows firms to destroy at least part of initial money creation by repaying bank loans. Financial markets come into play by intermediating savings and giving firms the possibility to pay back the full amount of bank credits. In fact, any money that is kept idle and is neither spent for consumption goods nor invested in financial assets will remain within the circuit, not allowing firms to repay their initial finance.

Despite the primary MCT concern about financial-real interactions, a few contributions in this strand of literature have devoted attention to financialization and its impact on the functioning of a monetary economy of production. Eatwell, Mouakil and Taylor (2008), Pilkington (2008), and Lavoie (2009) are among the first to include financialization, securitization, and shadow banking into a stock-flow-consistent (SFC) framework. ${ }^{1}$ They basically extended Godley/Lavoie-type balance sheets and flow-of-funds matrices in order to account for a simple macro-aggregated nonbanking' financial sector.

Fumagalli and Lucarelli (2011), Seccareccia (2013), Passarella and Sawyer (2013), and Passarella (2014) note that financialization (also) consists in a sort of reversal in the surplus and deficit financial positions traditionally attached to, respectively, households and non-financial businesses. On the one hand, commercial banks have expanded money creation in favor of households. Accordingly, households have increasingly run into net deficit positions, and household debt has risen enormously. On the other hand, non-financial corporations have increasingly deployed large net savings in financial markets in equity buybacks or the accumulation of structured financial assets rather than using them to support real-side investment.

Notwithstanding these attempts to reconcile financialization with the MCT, Lysandrou (2013) argues that the attention of circuitists has been largely misplaced to changes in economic actors' net financial positions, whilst they neglect to describe the terrific push by financial operators toward the commodification of financial relationships. Lysandrou considers such a shortcoming as a proof of circuit theory in-built inability to describe financialization and consequently the functioning of contemporary capitalistic (financialized) economies.

Albeit disagreeing with Lysandrou when he denies the potential insights deriving from the application of the MCT framework to the analysis of financialized economies, we believe that much has been overlooked in the literature. In particular, the abovementioned works only provide a rough description, if any, of the new practices that have recently emerged in financial markets and have effectively led to the financialization, securitization, and commodification of financial relationships. Yet, the monetary circuit clearly shows how money flows among different sectors in order to guide the functioning of a monetary economy of production. This same perspective can fruitfully be applied to the financial markets to understand the macro dynamics occurring between the different 
and heterogeneous components of the financial system and between the real and the financial side of the economy.

This paper takes inspiration from the above literature and aims at providing a picture of an amended monetary circuit in the era of financialization. Differently from previous contributions, we focus on changes taking place within modern financial systems and on the interactions between the different financial sectors and the real side of the economy. Indeed, thanks to the use of the Flow of Funds dataset and of the Stock Flow Consistent declination (Lavoie 2004) of the monetary circuit, we apply a social accounting perspective to the financial side of the economy. This allows us to understand the functional role of the different financial sectors usually aggregated under the generic label of "financial system". In practice we describe new relationships connecting real sectors and banks to non-bank financial sectors by means of simple but comprehensive graphical and balance sheet analyses of both real side and financial flows of funds.

In order to do so, this paper also hinges upon some articles about the shadow banking system and financial innovations such as asset securitization, sale-and-repurchase agreements (henceforth REPOs), and credit default swaps (henceforth CDS) (see Adrian and Shin, 2010; Adrian and Ashcraft, 2012; Gorton, 2010; Gorton and Metrick, 2009 and 2010; Stein, 2010). We develop an extended scheme of the monetary circuit in which a much more expanded and detailed financial sector (al least with respect to previous works) is eventually inserted into traditional real-financial relationships. We portray a sort of inside-finance circuit with links and leaks with the real side of the economy, and with the standard monetary circuit. ${ }^{2}$

Our final object is twofold. First, we try to portray 'commodification' practices characterizing modern financial systems. Second, and perhaps more relevantly, we provide some insights on the effects that new inside-finance mechanisms may have on the functioning of the monetary circuit, on the flux and reflux of money, on the way in which the circuit closes. Our paper brings two novelties with respect to the two strands of literature cited above. On the on hand, with respect to traditional monetary circuit models, we provide a much more detailed description of the functioning of modern financial systems, and we shed light on the otherwise obscure process of financialization. On the other hand, regarding the literature on shadow banking, we depart from its strict microeconomic logic. To the contrary, we adopt a macroeconomic perspective and try to highlight some systemic consequences of financialization by introducing financialization practices into the macroeconomic framework of the monetary circuit. In a way, through this revised, updated and, in a sense, financialized version of the monetary circuit, our paper tries to give some hints on how recent financial innovations may affect the functioning and the stability of a modern monetary economy of production.

The paper is organized as follows. Section 2 presents some stylized facts linked to the emerging features of modern financial systems before and after the recent financial crash. Section 3 compares the traditional monetary circuit scheme with an extended version including modern inside-finance interactions. Section 3 also translates the logic of the monetary circuit into the language of stockflow-consistent matrices, describing balance sheet and flow-of-funds relationships between realside and financial actors, as well as among different financial agents. Section 4 describes how the financialized monetary circuit eventually works and how financialization has altered the development and the functioning of the traditional monetary circuit. Section 5 concludes. 


\section{Modern Financial Systems: Some Stylized Facts}

This section aims to identify some stylized facts about financial system's dynamics and financialization in the last forty years. Previous contributions on this point mostly provided a more aggregated perspective by focusing only the financial system as a whole. Here we adopt a more disaggregated stand. In particular, our main goal is to show how the evolution of financial markets reflects on the dimension and composition of the balance sheets of the other sectors of the economy. We focus on the US economy due to the large availability of data concerning the composition and evolution of financial operators' balance sheets.

Figure 1 clearly shows that the total value of financial assets as a share of GDP remained pretty constant until the beginning of the 80s. Thanks to financial deregulation - starting in the second half $70 \mathrm{~s}$ and gathering momentum in the $80 \mathrm{~s}$ - the financial side of the economy has boomed, from being twice the GDP in 1975 to five times larger in 2013. ${ }^{3}$ Financial markets did not merely grow dramatically in size, they also mutated their composition.

Figure 1 - Financial sector’s total assets value over GDP.

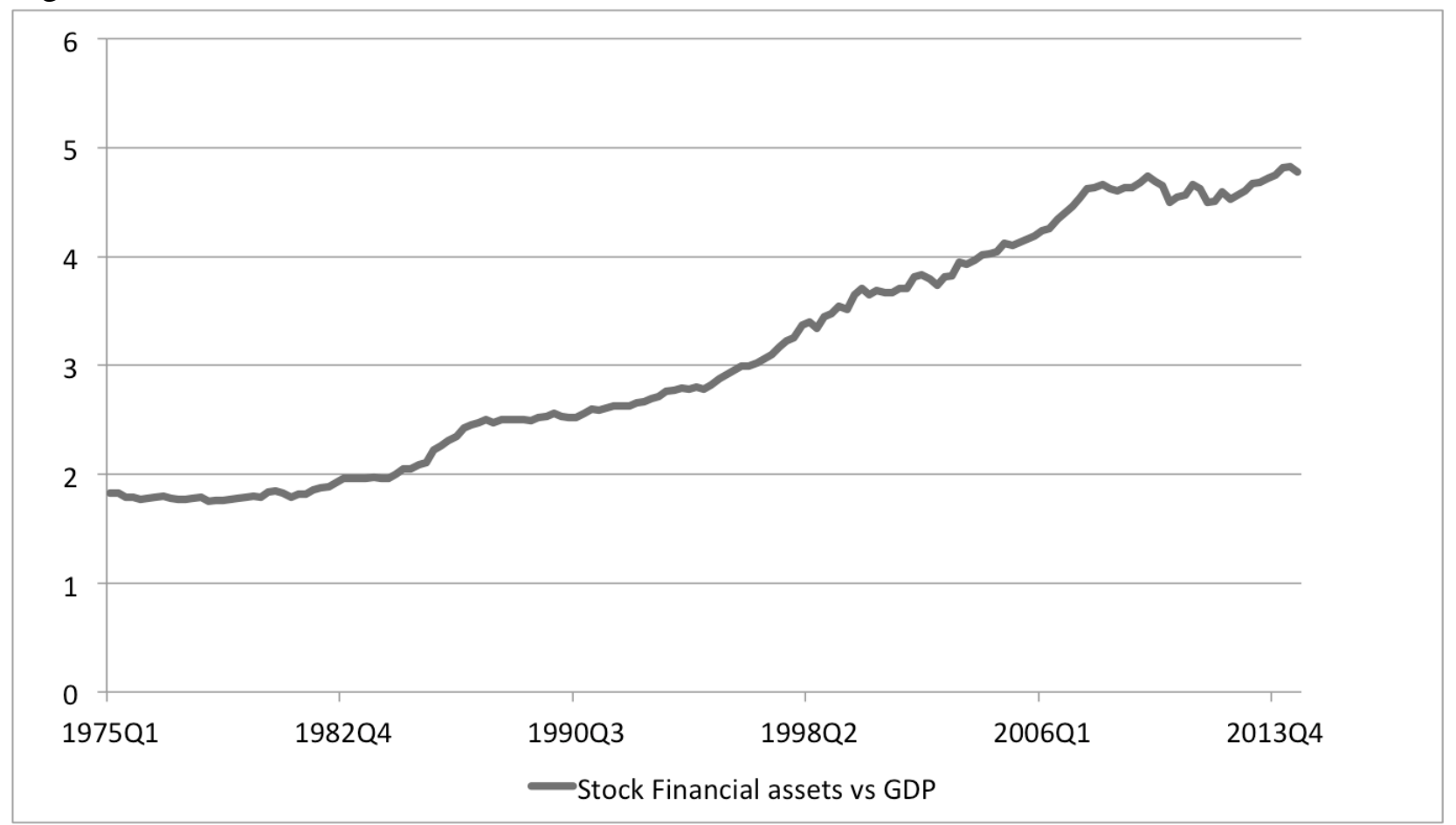

Source: FED’s Flow of Funds (Z1) and authors' computation.

Relying on the social accounting structure used by the Flow of Funds accounting system of the FED, we can try to understand the major characteristics of such a transformation. In order to reach this goal this work will try to account for the functional role of the aggregated sectors constituting the US economy, both in its real and financial sides. For the sake of clarity and in order to keep adherence to the analysis developed in the following section, in Figure 2 we grouped the twentyone subsectors, in which the FED's Flow of Funds subdivide the US financial system, into nine. Figure 2 shows the relative size of each sector in which we partitioned the financial system. 
Figure 2 - Financial operators’ shares of total financial assets.

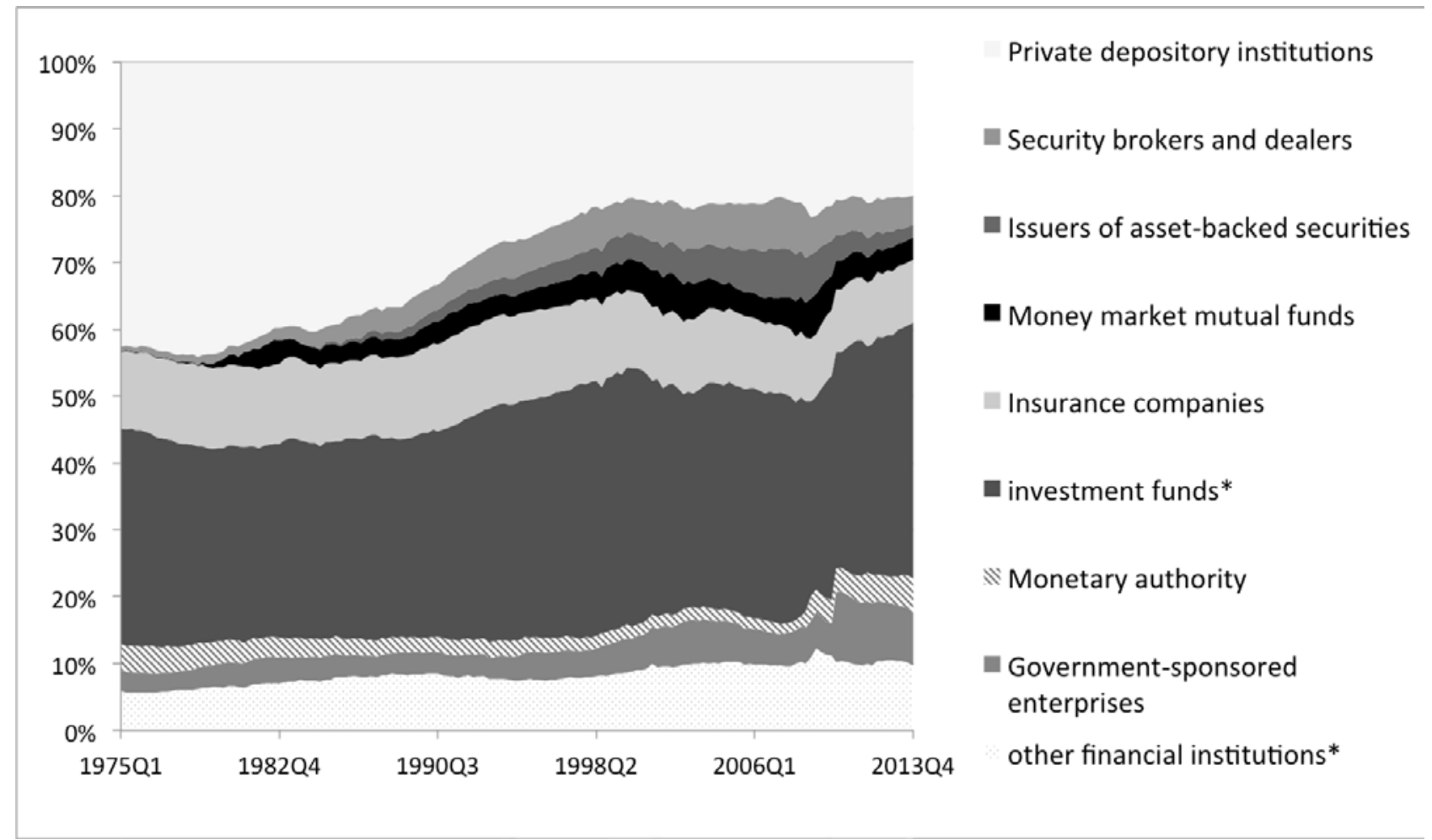

Source: FED’s Flow of Funds (Z1) and authors’ computation

What emerges is that the size of 'Private Depository Institutions' (which can be considered as a proxy for commercial banks) decreased from above $40 \%$ to around $20 \%$. This was due to the rapid expansion of financial operators, which were previously at the margin of the financial markets. We refer to Money Market Mutual Funds (henceforth MMMFs), Issuers of Asset-Backed Securities, and Security Brokers and Dealers. ${ }^{4}$ It is interesting to notice how these 'new' key sectors blossomed in the period before the 2007 subprime crisis and saw their relative importance decrease significantly in the aftermath. Another piece of information emerging from the graph regards the steep rise in the size of the 'Government Sponsored Enterprise' 5 due to both the new accounting rules and the role of the GSE in the FED's quantitative easing.

The two following graphs refer to the assets held by the whole financial system providing a clear depiction of some of the financial dynamics taking place. Figure 3 shows the main categories of assets. Figure 4 disaggregates the category 'Credit Instruments'.

The major outcome of Figure 3 is an increase in the role of equity, characterized by a certain level of volatility whose downturn coincides with the major financial crises of the last decades (1987, and most of all 2001 and 2007). The biggest component of assets is 'credit market instruments'. On top of that, Figure 3 also allows to appreciate the growth in the amount of REPOs (Federal Funds and Securities REPOs), whose role first increased through the 80s, then stabilized since the 90 s as one of the major components of the financial system, and finally severely collapsed in the aftermath of the crisis. 
Figure 3 - Financial operators’ main assets (as a share of total assets).

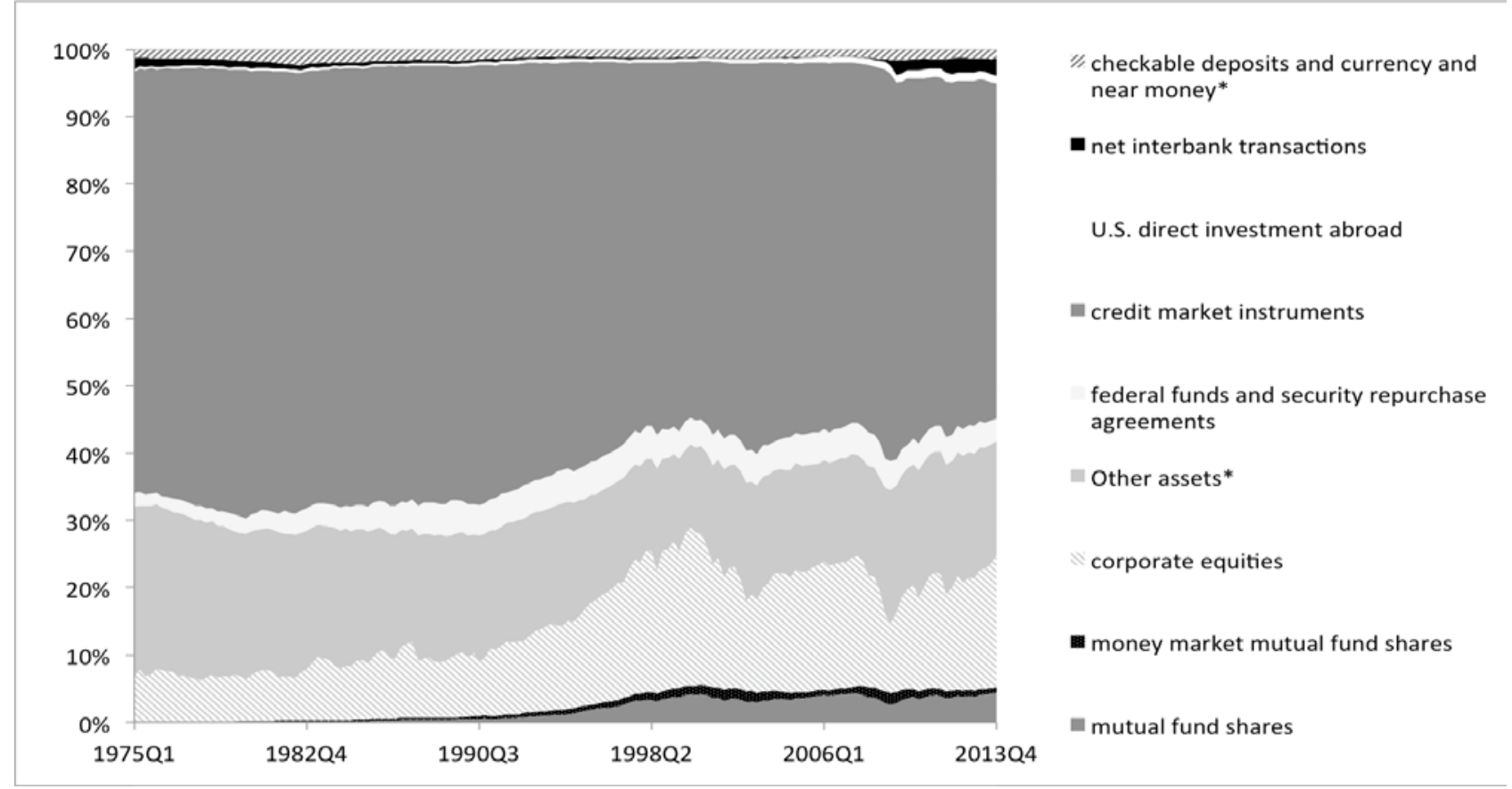

Source: FED’s Flow of Funds (Z1) and authors' computation.

In Figure 4, we can observe some changes in the composition of the 'credit market instruments' sub-group. Two dynamics appear to be particularly relevant: first, the pronounced increase in the role of mortgages to the detriment of other types of loans, especially in view of the approaching crisis; second, the growing importance of securities other than 'Treasuries Securities'. These two dynamics, one linked to mortgages and the other to securitization, are crucial for our analysis and will be at the core of our interpretation of a financialized monetary circuit.

The peculiar dynamics of the REPOs is hard to be seen neatly amidst all the assets included in Figure 3 and can be better investigated in Figure 5, which plots the value of the stock of REPOs with respect to GDP, both as an asset (continuous line) and as a liability (dotted line), for the financial system as a whole, and then specifically for the core sector trading in these assets, namely brokers and dealers. The graph is highly telling. First, it shows the rapid ascent of the value of REPOs in the way towards the 2007-2008 financial meltdown and its subsequent vertical collapse after the crisis outbreak. Second, it shows that brokers and dealers were by far the main traders of this kind of asset. Interestingly, in the years preceding the financial crisis, the increase of REPOs as a form of financing of investment banks has been much more marked than its usage by investment banks themselves as a possible investment opportunity. 
Figure 4 - Sub-groups of 'credit market instruments’ (shares).

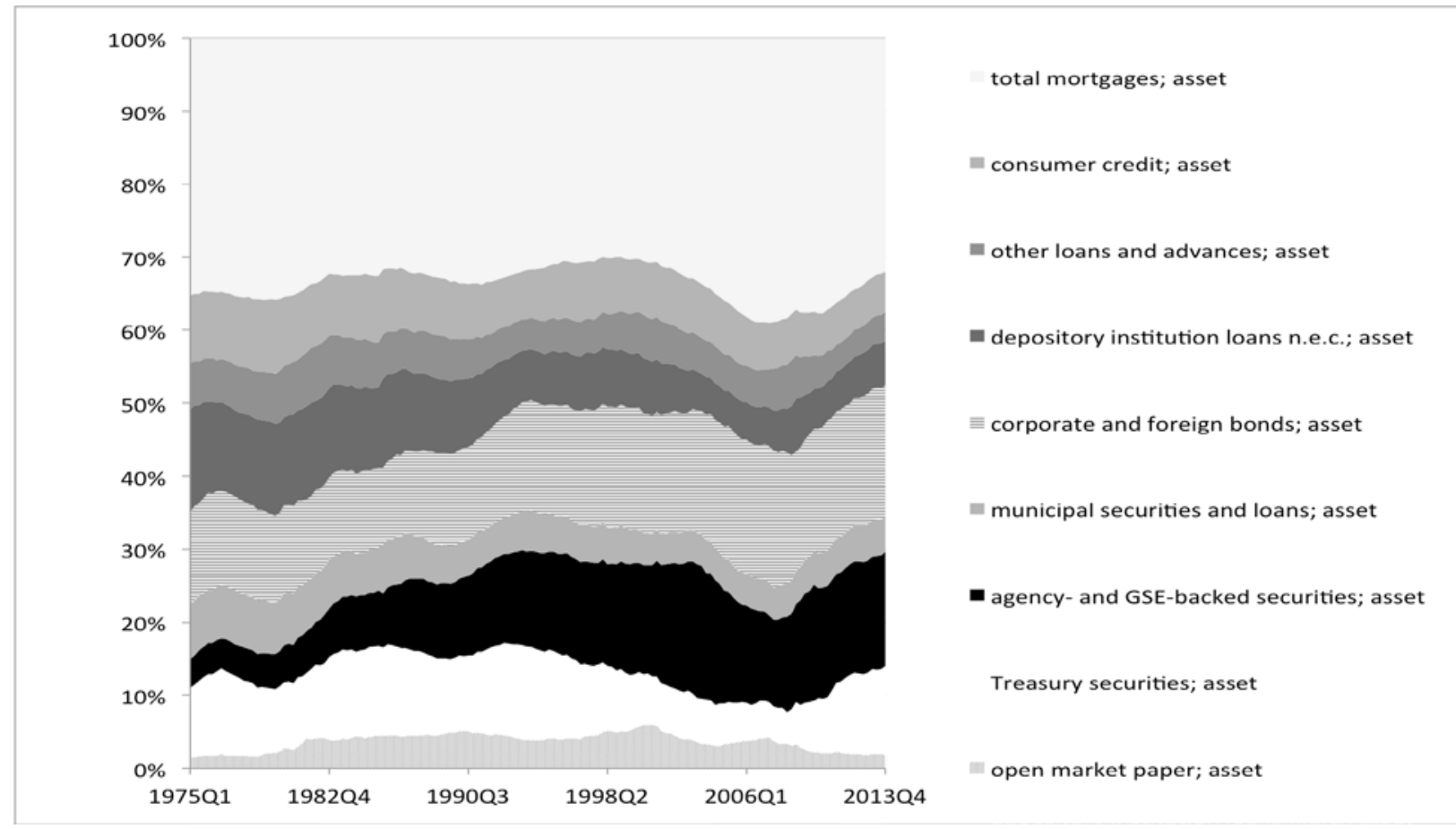

Source: FED’s Flow of Funds (Z1) and authors’ computation.

The first five Figures highlight the metamorphosis of the financial system. However, what was the role of the traditional banking system? The balance sheets of commercial banks changed deeply as can be seen in Figure 6. Real estate became the core business, more than doubling its relative weight in commercial bank balance sheets from around 13\% in 1975 to 32\% of total assets held in the sector just before the crisis. This had its counterpart in a significant decrease of industrial and commercial loans while securities kept a rather stable share around 17\%-20\%.

The effects of the crisis on commercial bank balance sheets can be seen in the sudden and dramatic interruption of interbank loans in 2007, and in the ensuing major increase in cash assets, due to Bernanke's intervention through the quantitative easing. In social accounting someone's asset is someone else's liability, likewise this increase in commercial bank real estate assets is mirrored by the increase in household indebtedness, as can be seen in Figure 7, which also shows the level of indebtedness of the corporate and noncorporate financial sectors (respectively NFC and NFNC). 
Figure 5 - Stocks of REPOs in financial sectors' and broker and dealers' balance sheets (as a share of GDP), assets and liabilities.

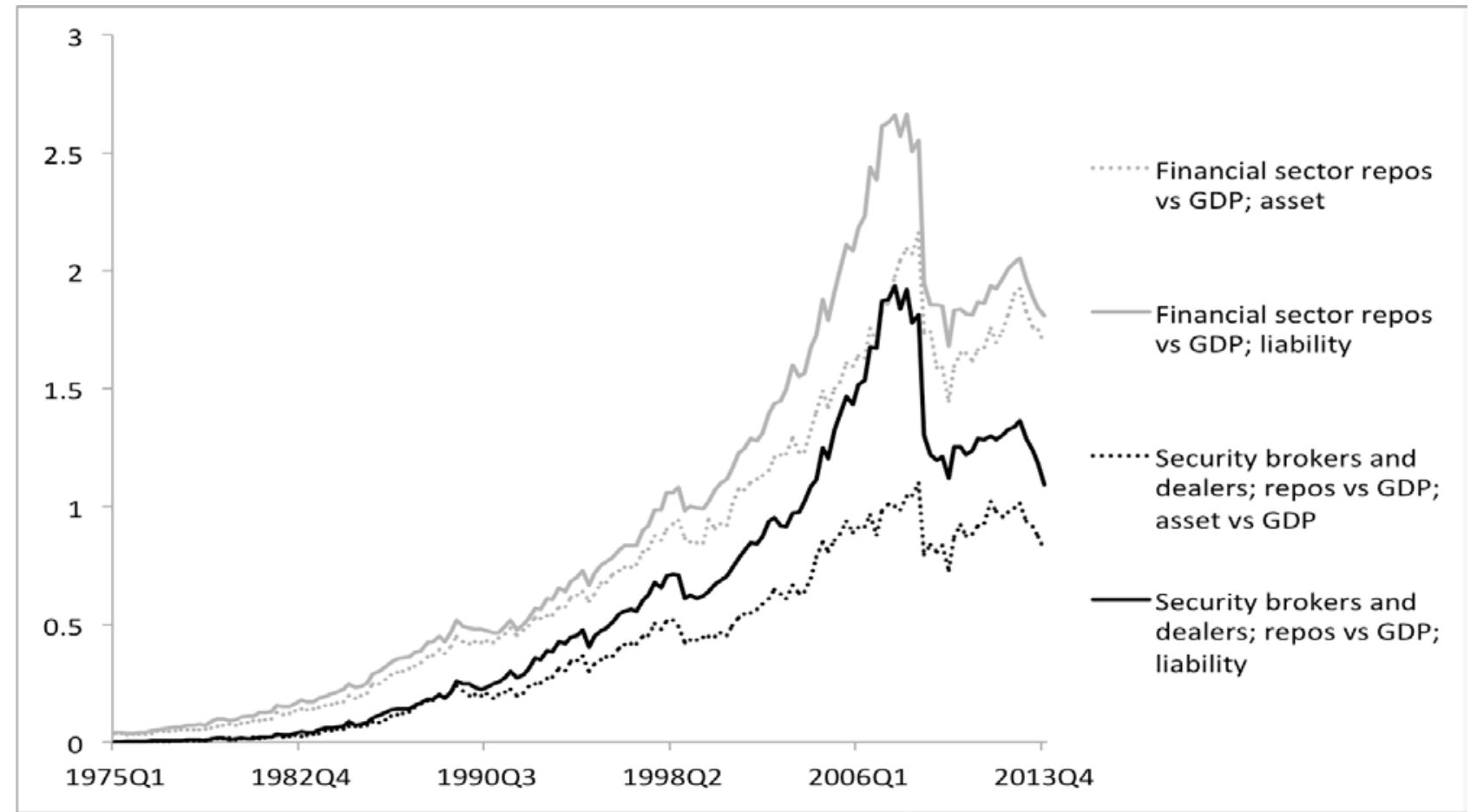

Source: FED’s Flow of Funds (Z1) and authors' computation.

Figure 6 - Composition of commercial banks’ balance sheet (shares).

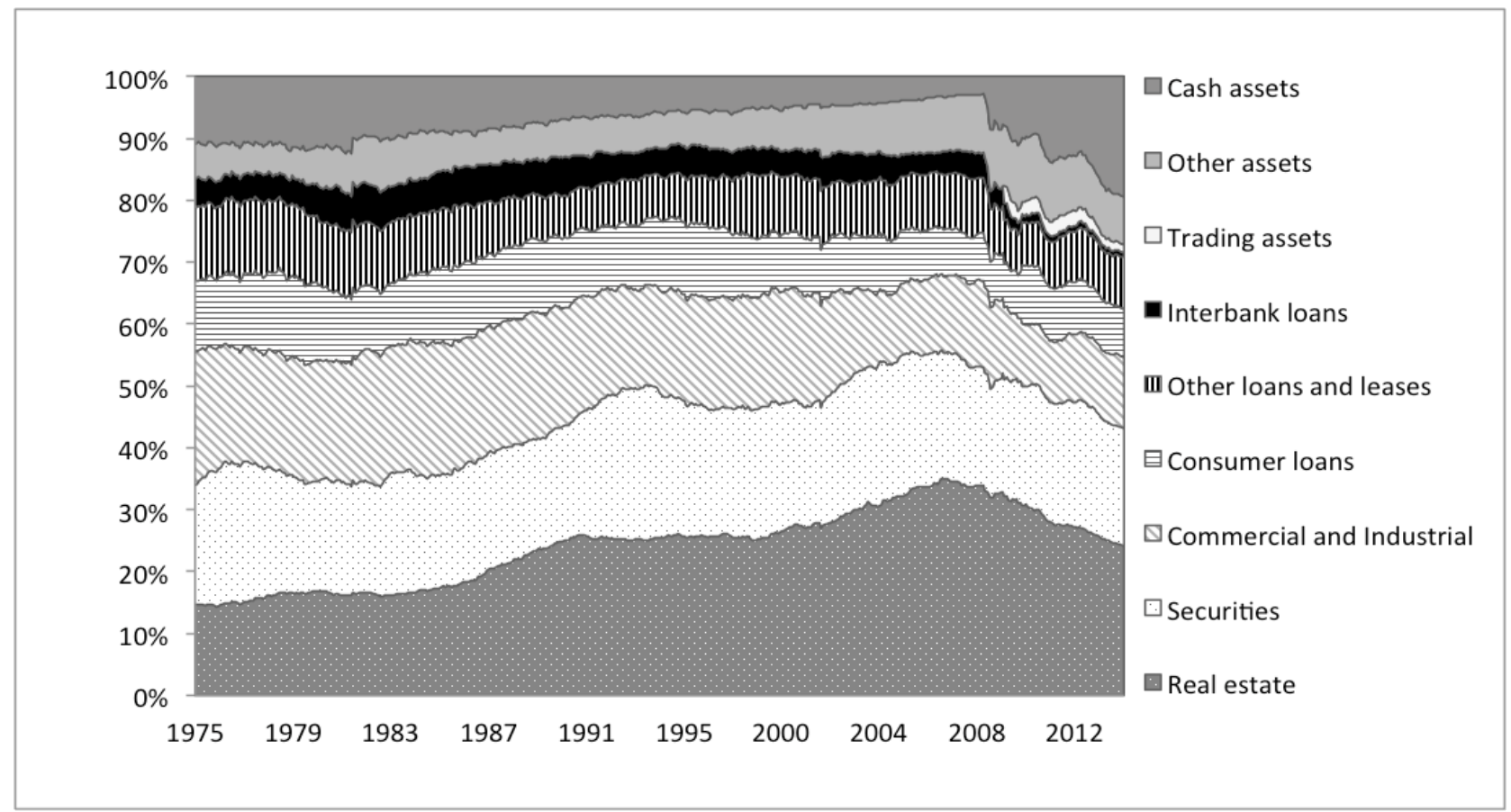

Source: FED’s Flow of Funds (Z1) and authors' computation. 
Figure 7 - Private non-financial sectors’ liabilities (share of GDP).

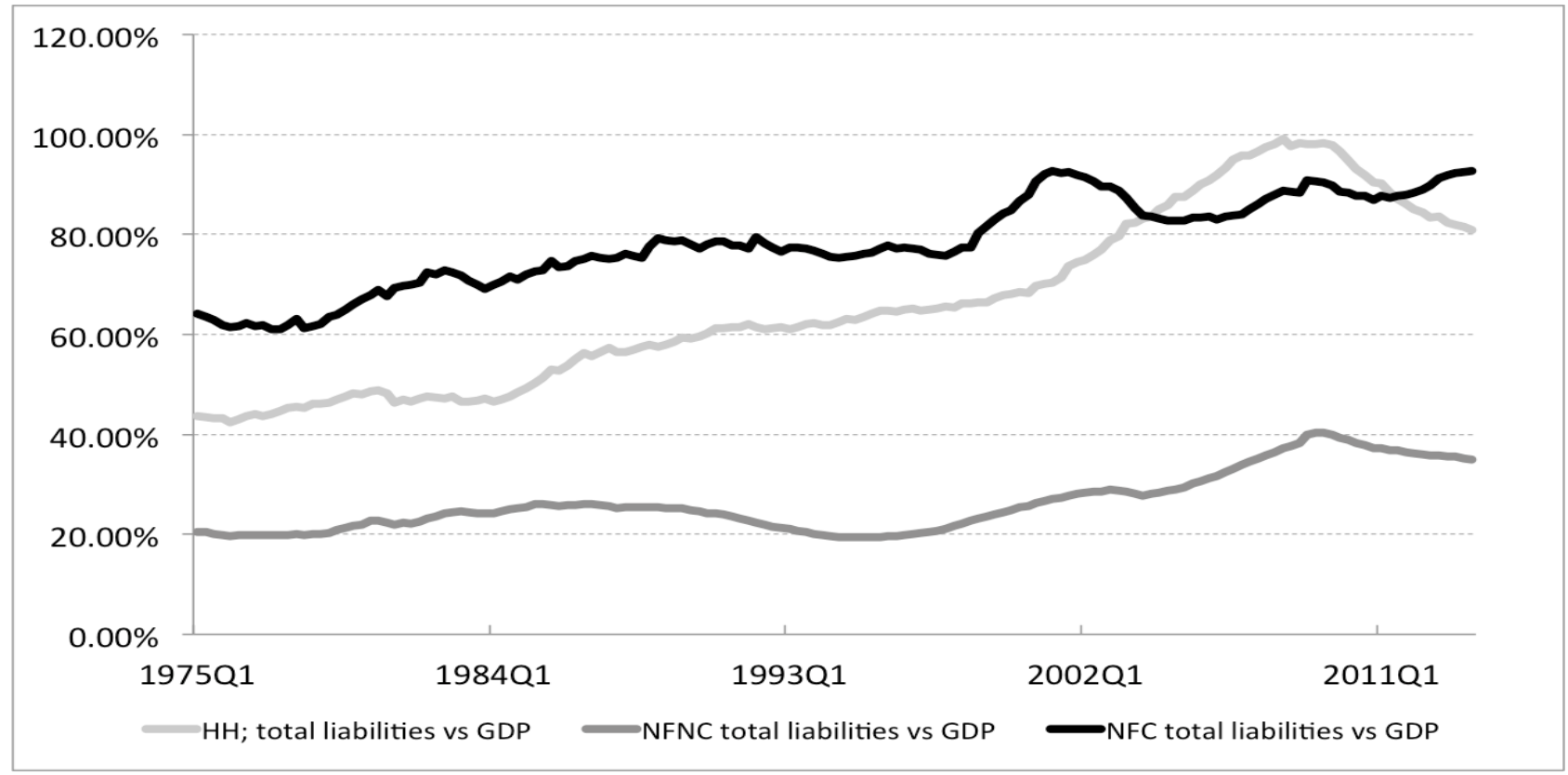

Source: FED’s Flow of Funds (Z1) and authors’ computation.

Figure 8 plots the value of the total assets held by MMMFs (divided by the GDP), and by the value of total assets held by the whole financial system. The value of its assets raised from almost scratch at the beginning of the 80s to a peak of one-fourth of the value of GDP, accounting for 5\% of total assets in the financial system in 2007. A core element emerging from the graph is the level of volatility. During both the 'dot.com' crisis in 2001 and the subprime crisis, its value diminished dramatically not only with respect to GDP, but also with respect to the financial system as a whole. This means it experienced higher volatility than the rest of the financial system.

Figure 8 - MMMFs' assets as a share of total financial sector's assets and of GDP.

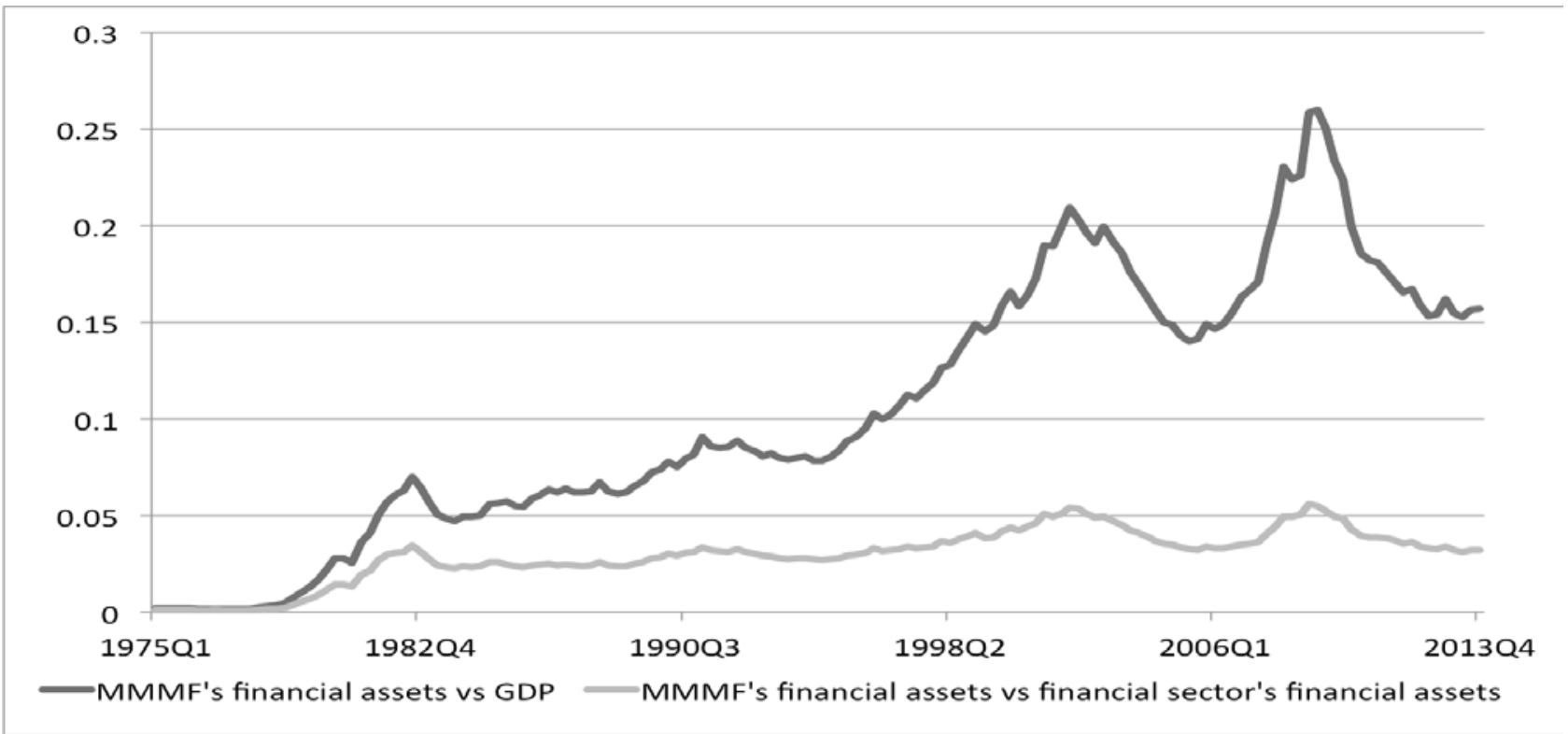

Source: FED’s Flow of Funds (Z1) and authors’ computation. 
Figure 9, showing the same graphs for issuers of asset-backed securities, is even more striking. The steepness of the rise and the subsequent fall is dramatic. From the beginning of the 80s to 2007, the value of assets held by these new institutions hit roughly one-third of the GDP and 7\% of all financial assets held by the whole financial sector. Unlike MMMFs, issuers of asset-backed securities appear not to have suffered the 'dot.com' crisis while the subprime crisis seems to have had a devastating effect on these institutions.

Figure 9 - Asset-backed security issuers' assets as a share of total financial sector's assets and of GDP.

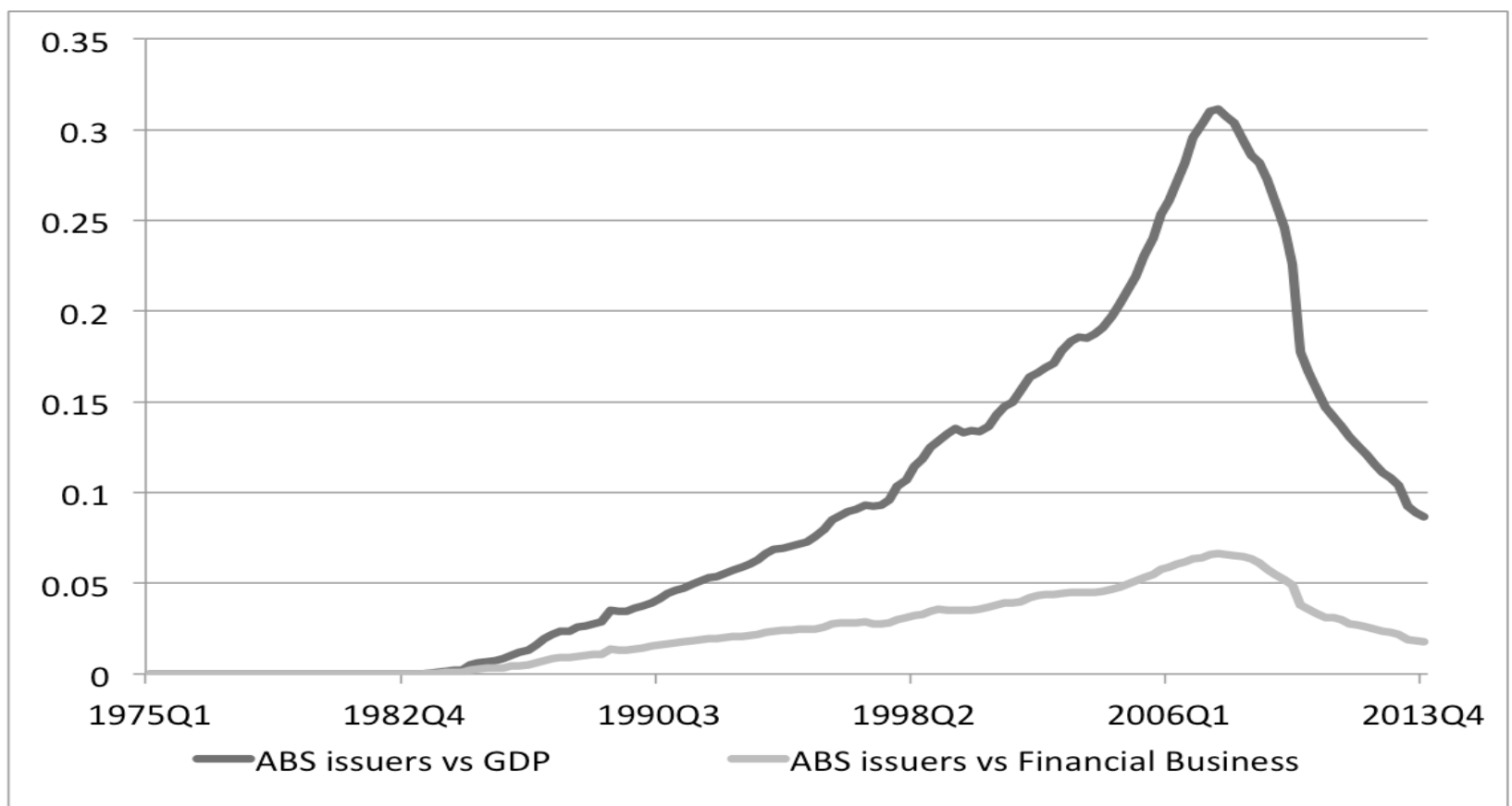

Source: FED’s Flow of Funds (Z1) and authors’ computation.

Securities Brokers and Dealers have experienced a similar path (see Figure 10). In fact, the size of their balance has been steadily expanding from the beginning of the 80s until the subprime crisis, both with respect to GDP (investment banks' assets-to-GDP ratio reached 32.6\% in 2007 from $1.1 \%$ in 1975 ) and to the whole financial sector (6.9\% in 2007 from $0.5 \%$ in 1975). All these three sectors appear not to have recovered from the sub-prime crisis, exhibiting a smaller balance sheet than in 2007.

Finally, according to Figure 11, 'Investment Funds' have become the main components of the financial system and have kept a rather stable relative quota within the financial system, approximately around 30-35\% of its size. This sector experienced different trends with respect to asset-backed security issuers, MMMFs, and Security Broker and Dealers. Unlike the former, it saw its balance sheet shrinking as a consequence of the two crises (dot.com and sub-prime). Unlike the previous three groups, it seems to have fully recovered, and its balance sheet is now larger than it was before the crisis (still with respect to the GDP). 
Figure 10 - Broker and Dealers' assets as a share of total financial sector's assets and of GDP.

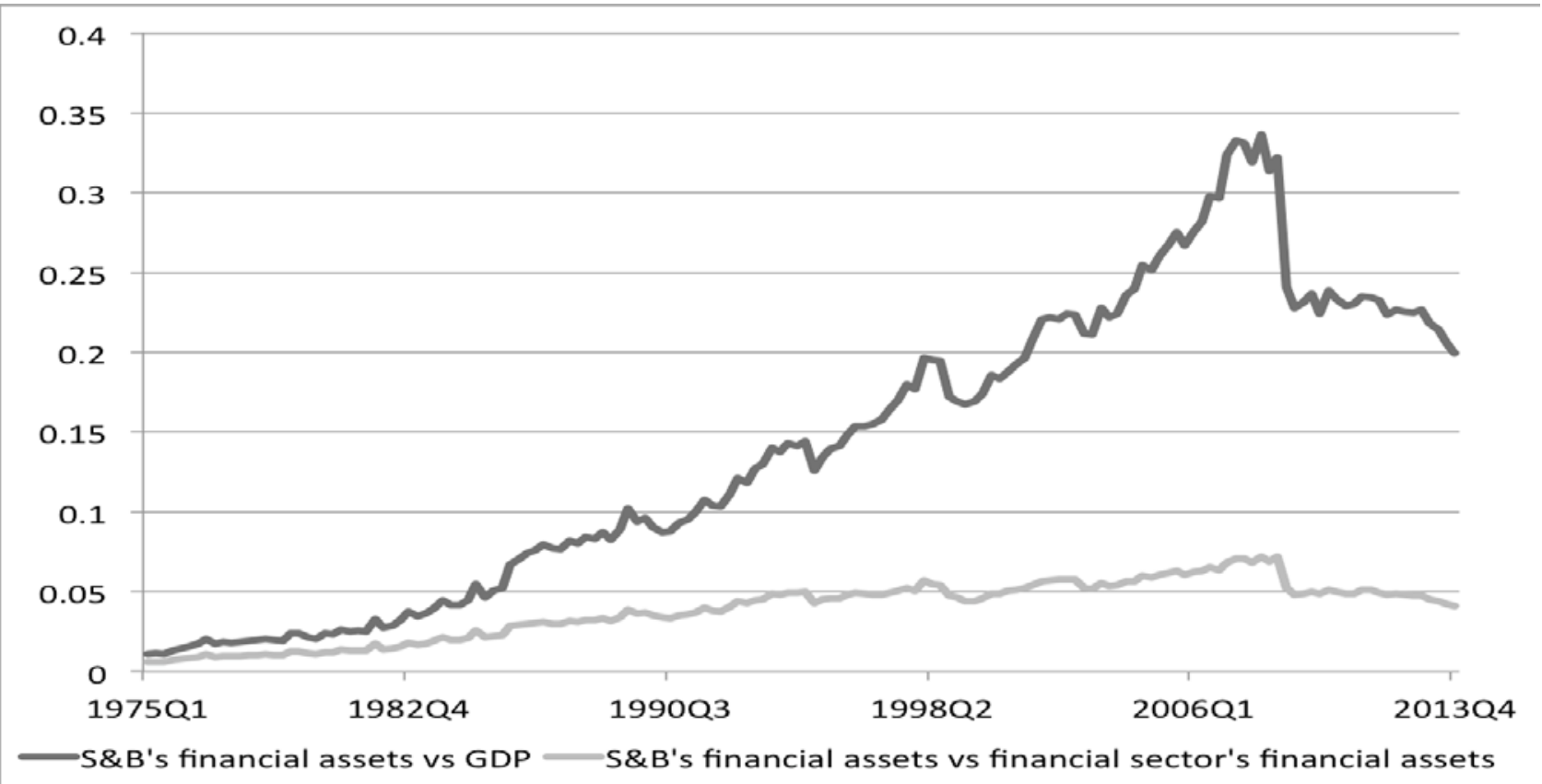

Source: FED’s Flow of Funds (Z1) and authors’ computation.

Figure 11 - Investment Funds’ assets as a share of total financial sector's assets and of GDP.

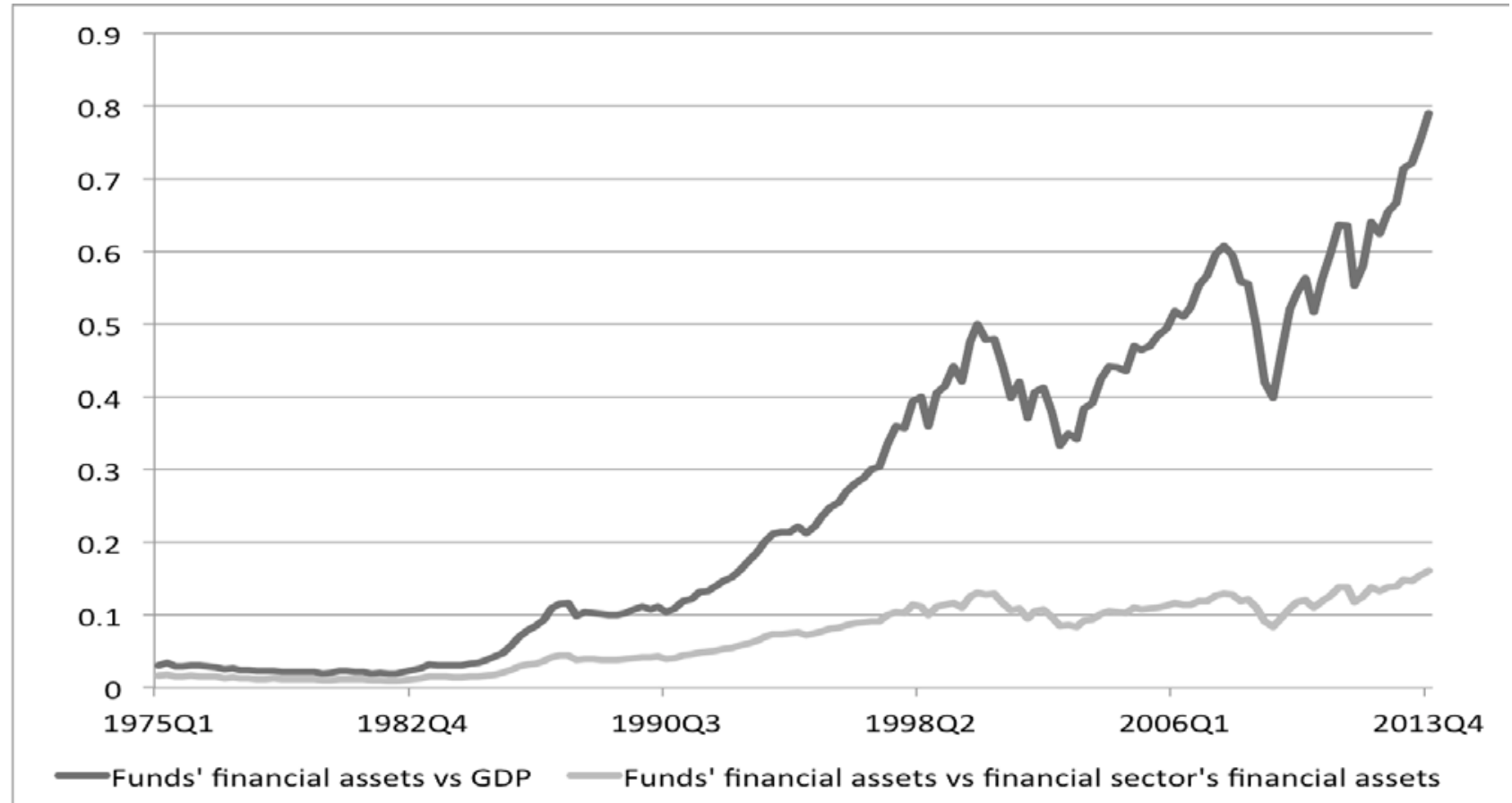

Source: FED’s Flow of Funds (Z1) and authors' computation.

To sum up, we can highlight the main stylized fact emerging in this section. First, the financial sector has been bloated with respect to the output of the economy. Second, commercial banks have been increasingly focusing their business on mortgages. Third, the household sector has become increasingly indebted. Fourth, three sectors experienced a boom when heading toward the 2007 crisis and have not recovered since then, namely Money Market Mutual Funds, ABS Issuers and Securities Brokers and Dealers. Finally, Investment Funds have become the core sector of the 
financial system and have fully recovered after the crisis. In the following section, we will try to find an explanation for these stylized facts.

\section{The Traditional Monetary Circuit and its Financialized Version: A Comparison}

\subsection{The traditional version of the monetary circuit}

Figure 12 portrays the logic of a traditional monetary circuit within a closed economic system in which government and central bank are also considered alongside private economic agents. Furthermore, in Figure 12 we show the relationships between economic actors that mainly pertain to the real side of the economy (i.e. non-financial businesses, households, government) and financial operators. In line with the logic of the traditional monetary circuit theory, financial institutions are subdivided into commercial banks on the one hand and market-based institutions, say investment banks and institutional investors such as investment and pension funds, on the other hand. While the former are the providers of initial finance, investment banks and institutional investors intermediate part of households savings through financial market mechanisms hence making the closure of the circuit possible and providing firms with a further source of final finance, next to proceeds from sales. The whole set of financial operators we consider constitutes the financial sphere of the economy. In figure 12, the dashed grey line recollecting financial institutions represents the relative dimension of the financial side of the economy compared to the real side.

In Figure 12 the arrows connecting various economic agents to each other stand for the creation and circulation of money (i.e. means of payments in the form of cash or, more relevantly, bank money). We draw couples of bi-directional arrows in the case of linkages between the real side and the financial side of the economy. In our mind, they stand for double-entry bookkeeping principles informing financial relationship accounting. The creation and provision of new purchasing power by commercial banks in favor of non-financial businesses through initial finance is mirrored by the transcription of new loans on the asset side of commercial bank balance sheets.

According to the standard monetary circuit story, circulation of money opens with initial finance, i.e. new bank money that commercial banks create on demand, mainly from the non-financial business sector. ${ }^{6}$ After this opening stage, new bank money flows from firms to households in the form of wages. In the representation of the circuit put forward in Figure 12, we included the public sector. Government purchases goods from firms and pays wages to households. Within this framework, the central bank endogenously advances new base money to commercial banks in order to allow them to meet their reserve requirements and let the payment system work smoothly.

Households get loans from commercial banks to finance durable goods consumption and/or, more typically, home buying. Household expenditures and government purchases imply money moving from their bank account back to firms. In addition to this, households allocate their savings among liquid and illiquid assets. Variations in the stock of household demand deposits represent new money remaining (i.e. not destroyed) at the end of the circuit once consumption decisions and the allocation of savings among different assets have taken place.

According to the endogenous money theory, this new money creation is the outcome of initial loans provided by commercial banks. In general, savings in the form of illiquid assets pass through the mechanisms of financial markets from surplus units (households) to deficit units (non-financial business and government). Revenues from selling of goods and services, as well as resources 
recollected on financial markets, are the final finance, which eventually allows firms (and government) to repay initial loans. In this way, the new money created at the beginning of the circuit thanks to initial finance is at least partially destroyed at the end of the circuit.

Three points are worth stressing regarding the logic of the traditional monetary circuit story as described so far and graphically represented in Figure 12.

First, the behavior of financial actors and the financial sphere of the economy are described as functional to the real side. Financial actors create new resources or intermediate existing ones in order to make real sector production and consumption decisions possible. In a way, the financial system could not exist without the real side of the economy and vice versa.

Second, commercial banks and market-based financial institutions represent different parts of the financial world absolving different functions and without close ties among each other. In the traditional monetary circuit story, these institutions somehow perform complementarily, but welldistinguished functions. The difference being that banks create money and the rest of the financial sectors does not.

Third, economic agents are clearly divided into surplus units, namely households, and deficit units, namely firms and government. Despite the existence of consumption loans and mortgages, households emerge as economic units running financial surpluses. Firms and governments, on the contrary, are the natural destinations of final finance. They issue corporate bonds, equities, and government bonds in order to finance their investment projects and repay initial loans. 
Figure 12 - Real-side and financial-side interactions in a traditional monetary circuit.

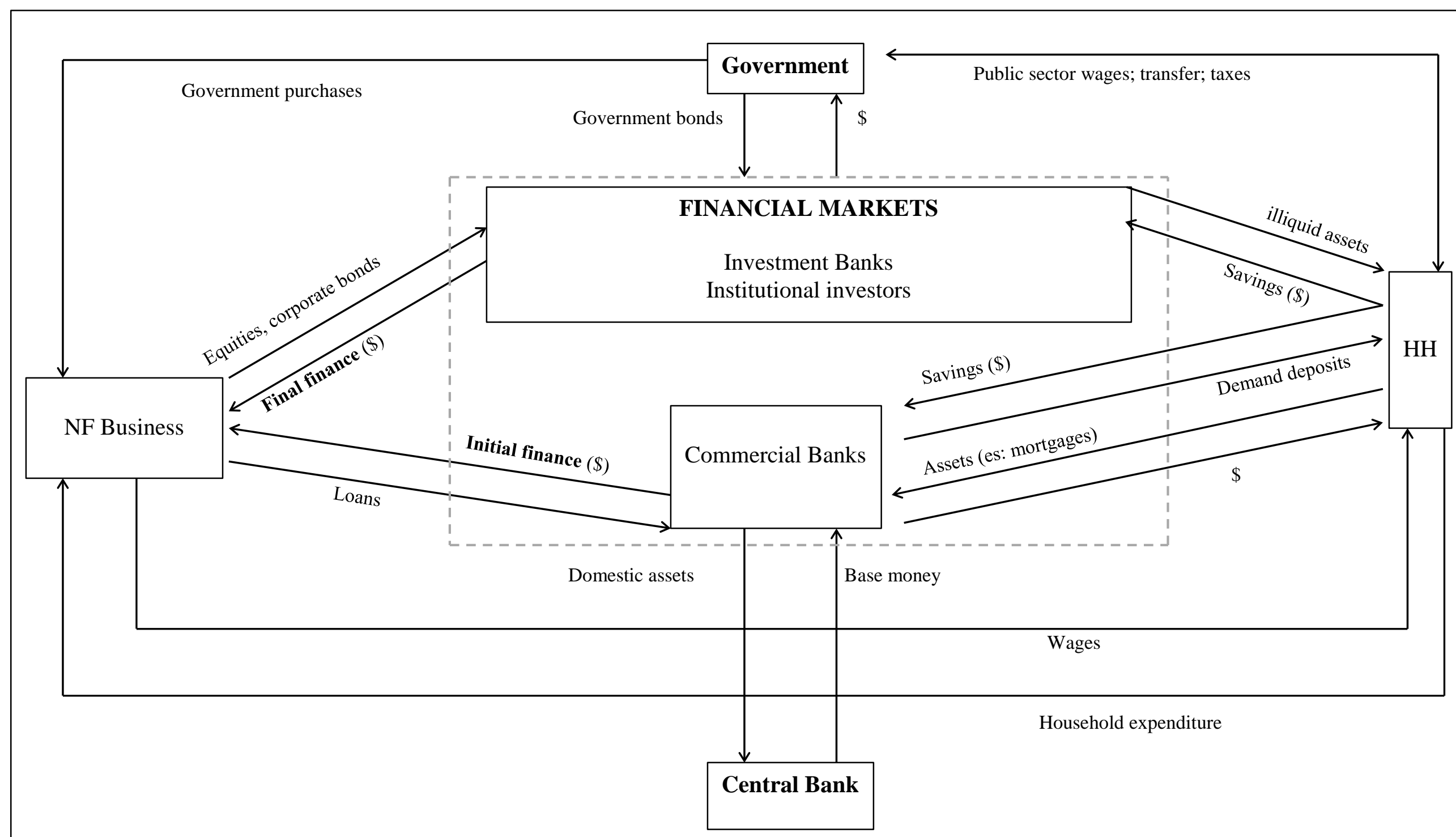


We present a more formal accounting of the relationships portrayed in Figure 12 through the flow-of-funds (fof) Matrix 1a reported below. It resembles the one provided by Lavoie (2004) in a previous paper on the logical contiguity between the monetary circuit theory and the more recent SFC analysis of complex economic systems. Matrix 1a below extends the previous representation provided by Lavoie (2004) by explicitly considering market-based financial institutions.

In order to maintain things as simple as possible, in Matrix 1a, we neglect to consider public institutions such as government and central bank. Consistently with Figure 12, Matrix 1a shows the central role of commercial banks as providers of new funds enabling economic agents to take economic decisions and the monetary circuit to open. New loans conceded to firms $(\Delta L)$ allow them to implement production decisions (i.e. pay wages $W$ to households) and undertake investment plans $(\Delta K)$. New mortgages to households $(\Delta M)$ allow them to buy houses $(\Delta p H)$. From the 'capital column' of commercial banks, the 'loans-create-deposits' logic of the endogenous money theory clearly emerges.

The block of current transactions in Matrix 1a (upper-left part of matrix 1a) shows that, beyond wages, households also receive interest payments on accumulated deposits $\left(i D_{h}\right)$ from commercial banks, and rents on shares of tradable financial assets (iSh) from market-based financial institutions (MBB). ${ }^{7}$ Part of households' total disposable income is spent for consumption purposes $(C)$. Part of it is used to pay interests on mortgages (iM). Savings ( $S A V)$ are then allocated among increases in liquid assets (a variation of demand deposits $\Delta D_{h}$ ), increasing shares of tradable financial assets $(\triangle S H)$ and newly purchased houses. In this regard, according to the traditional monetary circuit, the more households abstain from consumption and accumulate liquid assets, the lower will be firms' capacity to repay back initial loans. A larger quantity of initial bank money will eventually remain in the circuit and not be destroyed.

As far as non-financial firms are concerned, on top of new loans from banks in order to cover current production expenditures, they get revenues from selling goods on the good market. They also get interests on banks' deposits $\left(i D_{f}\right)$. Last but not least, non-financial firms issue corporate bonds $(O)$ on financial markets, purchased by financial intermediaries. In the jargon of the monetary circuit literature, this represents final finance.

On the one hand, non-financial firms deploy available resources in order to meet interest payments on banks' loans and issued bonds, and to repay loans and/or bonds reaching maturity, i.e. 'hidden' negative terms behind net variations of ' $L_{f}$ ' and ' $O$ '. On the other hand, they accumulate assets in the form of illiquid new capital goods $(\Delta K)$ or variations in banks' deposits $\left(\Delta D_{f}\right)$. $F$ stands for non-financial firms' profits. For the sake of simplicity, we assume them not to be distributed.

Commercial banks create (bank) money ex nihilo through their activity of conceding new loans and mortgages. Accordingly, commercial banks receive interests on outstanding loans and pay interests on deposits $(D)$. Profits are $F_{b}$. Once again, for the sake of simplicity, we assume they are not distributed.

Non-bank financial institutions intermediate (part of) household savings by issuing securities, say investment funds' shares $(\triangle S H)$, and buying newly issued corporate bonds $(\triangle O)$. Current transactions of non-bank financial institutions, i.e. interests' proceeds, and payments, originate correspondingly to the above financial positions. Again, profits $F_{m b}$ are not distributed and, for simplicity, take the form of new liquid assets $\left(i D_{m}\right)$. 
Matrix 1a: Flow of Funds in the traditional version of the monetary circuit

\begin{tabular}{|c|c|c|c|c|c|c|c|c|c|c|}
\hline & \multicolumn{2}{|c|}{$\mathrm{HH}$} & \multicolumn{2}{|c|}{ FIRMS } & \multicolumn{2}{|c|}{ BANKS } & \multicolumn{2}{|c|}{ MBB } & \multirow[t]{2}{*}{$\Sigma$} \\
\hline & & Current & Capital & Current & Capital & Current & Capital & Current & Capital & \\
\hline \multirow{8}{*}{$\begin{array}{l}\text { Consumptio } \\
\text { Investment } \\
\text { Wages } \\
\text { interest on }\end{array}$} & & $-C$ & & $+C$ & & & & & & 0 \\
\hline & & & & $+\Delta K$ & $-\Delta K$ & & & & & 0 \\
\hline & & $+W$ & & $\cdot W$ & & & & & & 0 \\
\hline & Loans & & & $-i L_{f}$ & & $+i L$ & & & & 0 \\
\hline & Mortgages & $-i M$ & & & & $+i M$ & & & & 0 \\
\hline & Deposits & $+i D_{h}$ & & $+i D_{f}$ & & $-i D$ & & $+i D_{m}$ & & 0 \\
\hline & Obligations & & & $-i O$ & & & & $+i O$ & & 0 \\
\hline & Shares & $+i S H$ & & & & & & $-i S H$ & & 0 \\
\hline \multirow{7}{*}{$\begin{array}{l}\text { totals } \\
\text { change in }\end{array}$} & & $S A V$ & $+S A V$ & $-F$ & $+F$ & $-F_{b}$ & $+F_{b}$ & $-F_{m b}$ & $+F_{m b}$ & 0 \\
\hline & Loans & & & & $+\Delta L_{f}$ & & $-\Delta L$ & & & 0 \\
\hline & Mortgages & & $+\Delta M$ & & & & $-\Delta M$ & & & 0 \\
\hline & Deposits & & $-\Delta D_{h}$ & & $-\Delta D_{f}$ & & $+\Delta D$ & & $-\Delta D_{m b}$ & 0 \\
\hline & Obligations & & & & $+\Delta O$ & & & & $-\Delta O$ & 0 \\
\hline & Shares & & $-\Delta S H$ & & & & & & $+\Delta S H$ & 0 \\
\hline & houses & & $-\Delta p H$ & & & & & & & $-\Delta p H$ \\
\hline \multicolumn{2}{|l|}{$\Sigma$} & 0 & 0 & 0 & 0 & 0 & 0 & 0 & 0 & \\
\hline
\end{tabular}

The above flow of funds determines variations in the accumulated amount of agents' assets and liabilities, hence in economic agents' net worth $(N W)$. Matrix $1 \mathrm{~b}$ below reports assets held and liabilities issued by the various institutions we have considered so far. In Matrix $1 \mathrm{~b}$, we assume all economic agents other than commercial banks, which hold bank deposits as liquid assets. In our mind, such an assumption simply sheds light on commercial banks as pivotal institutions at the core of the payment system. While households may hold bank deposits as a store of value, other actors hold banks deposits mainly for everyday payments.

Matrix $1 \mathrm{~b}$ - Institutions' balance sheets in a conventional monetary circuit

\begin{tabular}{|c|c|c|c|c|c|}
\hline & $\mathrm{HH}$ & FIRMS & BANKS & MBB & $\Sigma$ \\
\hline Real Capital & & $+K$ & & & $+K$ \\
\hline Loans & & $-L_{f}$ & $+L$ & & 0 \\
\hline Mortgages & $-M$ & & $+M$ & & 0 \\
\hline Deposits & $+D_{h}$ & $+D_{f}$ & $-D$ & $+D_{m b}$ & 0 \\
\hline Obligations & & $-O$ & & $+O$ & 0 \\
\hline Shares & $+\mathrm{SH}$ & & & $-S H$ & 0 \\
\hline houses & $+p H$ & & & & $+p H$ \\
\hline$\Sigma$ & $N W_{h}$ & $N W_{f}$ & $N W_{b}$ & $N W_{m b}$ & $+(K+p H)$ \\
\hline
\end{tabular}

\subsection{An amended financialized monetary circuit}

There is no doubt that since 1970s the process of financial deregulation and financialization has radically changed the way financial institutions work and interact with the real economy, at least with respect to the prototype of the monetary circuit scheme considered above. In Figure 13, we portray an amended monetary circuit in which we try to introduce some relevant changes that have 
affected the financial side of the economy in the last three decades. Herein we list some points of departure from our description of a financialized economy, as reported in Figure 13, with respect to the traditional monetary circuit illustrated in Figure 12. To the best of our knowledge, Figure 13 is the first attempt to formally portray into a monetary circuit at least part of the complex financial linkages characterizing modern financial systems.

First, similarly to Figure 12, interactions between the financial sphere and the real side of the economy are portrayed through black continuous arrows. On the contrary, black dotted arrows stand for burgeoning financial relationships inside the financial system. In this regard, what is changed with respect to Figure 12 is the intensity of some financial-real side relationships and/or their causal direction. On the right hand side of Figure 13, the bold lines between commercial banks and households stand for the expansion of consumption loans and mortgages, and the ensuing increase in households' debt exposure towards the financial system (see Orhangazi, 2011; Passarella and Sawyer, 2013; Passarella, 2014). On the left-hand side of Figure 13, bold lines between nonfinancial businesses and the financial system now go both ways instead of being one-way. The logic is that several non-financial companies, in particular big corporations, have moved from being 'deficit units' searching for external finance into 'surplus units' running financial surpluses. Nonfinancial firms have diverted an increasing amount of resources towards the acquisition of financial assets instead of financing physical investment (Stockhammer, 2004; Crotty, 2005; Orhangazi, 2008 and 2011; Demir, 2009; Passarella, 2014).

Second, several contributions even from a mainstream tradition describe finance as an expanding industry in modern developed economies accounting for an increasing share of their GDP (Cecchetti and Kharroubi, 2012; Beck et al., 2014; Law and Singh, 2014). In Figure 13, the boundaries of the financial sphere, traced by the grey dashed lines, are much wider than what is portrayed in Figure 12. In our mind, this represents the expansion of the financial system with respect to the real side.

Third, the financial block of Figure 13 tries to account for some of the inside-finance changes discussed in Section 2, which have been basically overlooked by traditional monetary circuits. In Figure 13, bold letters are meant to stress the increasing importance MMMFs have gained in worldwide financial systems as deposit-like issuer institutions alternative to commercial banks. Moreover, the large size of the investment bank box (at least with respect to what is portrayed in Figure 12) captures the empirical evidence on the growing importance of brokers and dealers as fundamental market-makers institutions. In a way, it graphically portrays the impressive growth of investment bank balance sheets, at least until the outbreak of the 2007-2008 financial crisis (Adrian and Shin, 2010; Gorton and Metrick, 2010). It also underlines the crucial role of investment banks in generating a 'self-feeding financial circuit' that is partially decoupled from the real side circuit (see below). Last but not least, in the upper-right part of the financial block of Figure 13 we explicitly take into account insurance companies as distinct operators compared to other financial institutions. We do this in order to take onboard the fact that insurance companies have remarkably changed and extended the range of activities with respect to their very traditional function of savings intermediation. The case of American International Group's participation in over-thecounter derivative markets as providers of CDS contracts clearly stands out as the most astonishing example of such a change (Kane, 2013).

Fourth, modern financial systems feature the increasing evaporation of the traditional distinction between bank-centered financial institutions/relationships and market-based actors/links as imposed by the post-WWII tight regulation of the financial system. Since the mid 1970s, financial 
deregulation, the emergence and diffusion of securitization, Special Purpose Vehicles (henceforth SPV), REPOs, and new types of derivative products such as CDS have made this separation increasingly blurred and difficult to determine. Financial operators have started to run an increasingly large variety of activities and engage in dense financial networks. Previously welldetached and carefully distinguished financial institutions have become progressively intertwined in an extraordinarily complex system of connections. Dotted arrows in the financial box of Figure 13 get at least a small part of such a messy tangle. They describe the emergence in the last decades of a sort of financial circuit that is partially delinked from the real side of the economy.

\subsubsection{Building blocks a financialized monetary circuit}

Despite the outburst of the financial system as partially detached from the real economy, the run-up to the most recent worldwide financial crisis and the ensuing 'Great Recession' suggest that the grip of the financial system on overall economic dynamics is perhaps stronger than ever. On the one hand, a burgeoning financial activity and an expanding financial circuit might positively spur real side economic activity (Boyer, 2000; Aglietta, 2000; Van Treeck, 2008; Hein, 2011). On the other hand, such a dynamics is likely unstable. A brief description of the building blocks of our financialized monetary circuit may help to explain how it may influence, and perhaps destabilize, overall economic performances.

In the bottom part of Figure 13, commercial banks still perform their peculiar function of creating new purchasing power ex-nihilo. They continue to provide initial finance to both nonfinancial businesses and households. With respect to Figure 12, loans to households have become relatively more important than loans conceded to other actors. Furthermore, commercial banks may now create money when they take part in REPO agreements as lending counterparts of other financial institutions, typically investment banks.

After being created, bank money circulates through the circuit. On the one hand, non-financial firms use it to pay wages and undertake production activity, as well as to accumulate assets, both productive and unproductive financial ones. On the other hand, households allocate their disposable income (wages plus interests income) between consumption and savings. Investment banks may use liquidity obtained through REPOs to expand their business, open new financial positions and accumulate new assets, say asset-backed securities (henceforth ABS).

A significant departure with respect to Figure 12 and the standard functioning of the monetary circuit emerges. This is the newly available option of allocating savings among different financial instruments through the intermediation of different financial institutions. There are some differences with regards to both the demand side (which type of assets savers/financial operators demand) and the supply side (which kind of assets financial operators offer). Regarding demand, we already mentioned a sort of inversion of net deficit and surplus financial positions between nonfinancial firms, large corporations in particular, and households. In the case of non-financial firms, profits may remain 'liquid' and take the form of MMMFs shares rather than being used to finance productive investment. MMMFs will in turn use these funds in order to acquire (apparently) liquid assets such as asset-backed commercial papers (henceforth ABCP), or to take part in REPO agreements vis-à-vis investment banks. MMMFs, together with investment banks, stand out as relevant purchasers of ABCPs (MMMFs in particular) and ABSs (Adrian and Shin, 2010; Gorton and Metrick, 2010). ${ }^{8}$ 
On the supply side, the burgeoning (at least until the outbreak of the 2007-2008 financial crisis) supply of rather new financial instruments such as ABS, ABCP, and collateralized-debt-obligations (henceforth $\mathrm{CDO}$ ) has been largely dependent on the securitization of loans or mortgages by commercial banks. In the last decade, commercial banks have increasingly replaced the traditional 'originate and hold' practice with the 'originate, repackage and distribute' practice (Gorton and Pennacchi, 2005; Parlour and Plantin, 2008; Wray, 2007). In the bottom part of Figure 13, we describe it in the simplest way possible. ${ }^{9}$ Part of the assets of commercial banks is pulled and moved off their own balance sheets into legally distinguished entities such as SPV. SPV, in turn, buy commercial bank assets thanks to resources recollected on financial markets by selling ABSs and ABCPs to MMMFs and investment banks. From the point of view of commercial banks, securitization allows them to transform illiquid assets into marketable ones, and to sell them on financial markets in exchange for liquidity. It represents an indirect source of cheap finance through off-balance sheet mechanisms. Even more, securitization allows commercial banks to manage their own balance sheet in a flexible way, to gain margins of maneuver to further expand their own business, and to create more space for opening up new financial positions while still benefitting and profiting from previously created and then sold assets. When commercial banks sell assets to SPVs, they downsize the asset side of their balance sheet. Correspondingly, some liquid liabilities are destroyed, let say SPVs deposits. If we assume some commercial bank core capital to exist, commercial bank equity-asset ratio improves and leverage decreases, at least figuratively, after securitization. Commercial banks will now present more solid balance sheets and have a chance to expand their asset portfolio newly. ${ }^{10}$

Investment banks can finance ABSs purchases by issuing bonds to investment funds and insurance companies (see upper-right part of the financial block in Figure 13). Beyond this, they have increasingly recurred to REPOs as short-term means of financing (see Adrian and Shin, 2010; Gorton and Metrick, 2009 and 2010; Stein, 2010). In the bottom-right part of Figure 13, MMMFs stand out as relevant counterparts of investment banks in REPOs agreements. ${ }^{11}$ Furthermore, a selffeeding inner-finance cycle emerges in the event that commercial banks provide investment banks with fresh money through REPOs, and investment banks in turn use these resources to buy ABSs implicitly supplied by commercial banks themselves through securitization. ${ }^{12}$

Before August 2007, overconfidence in ABSs as safe and liquid assets was strengthened by the possibility to hedge financial positions through CDS contracts (see the top-right part of the financial block in Figure 13). The supply of CDS represents a significant discontinuity in the kind of financial services traditionally offered by insurance companies. CDSs allow CDS sellers to gain streams of payments in exchange for protection against default risks on insured assets. Insured financial institutions obviously buy CDSs in order to hedge risks in open financial positions, and increase the (perception of) solidity of their balance sheet. Even more, they can purchase CDS contracts as a remunerative 'autonomous' investment opportunity regardless of the existence of any insurable interest. The outgrowth of CDS contracts helped fueling financial cycles and financial hyperactivity in time of 'bonanza'. At the same time, they contributed to spread the subprime crisis to the whole financial system and jeopardized the financial solidity of too-big-to-fail (or toointerconnected-to-fail) insurance companies such as AIG. 
Figure 13 - An extended financialized monetary circuit

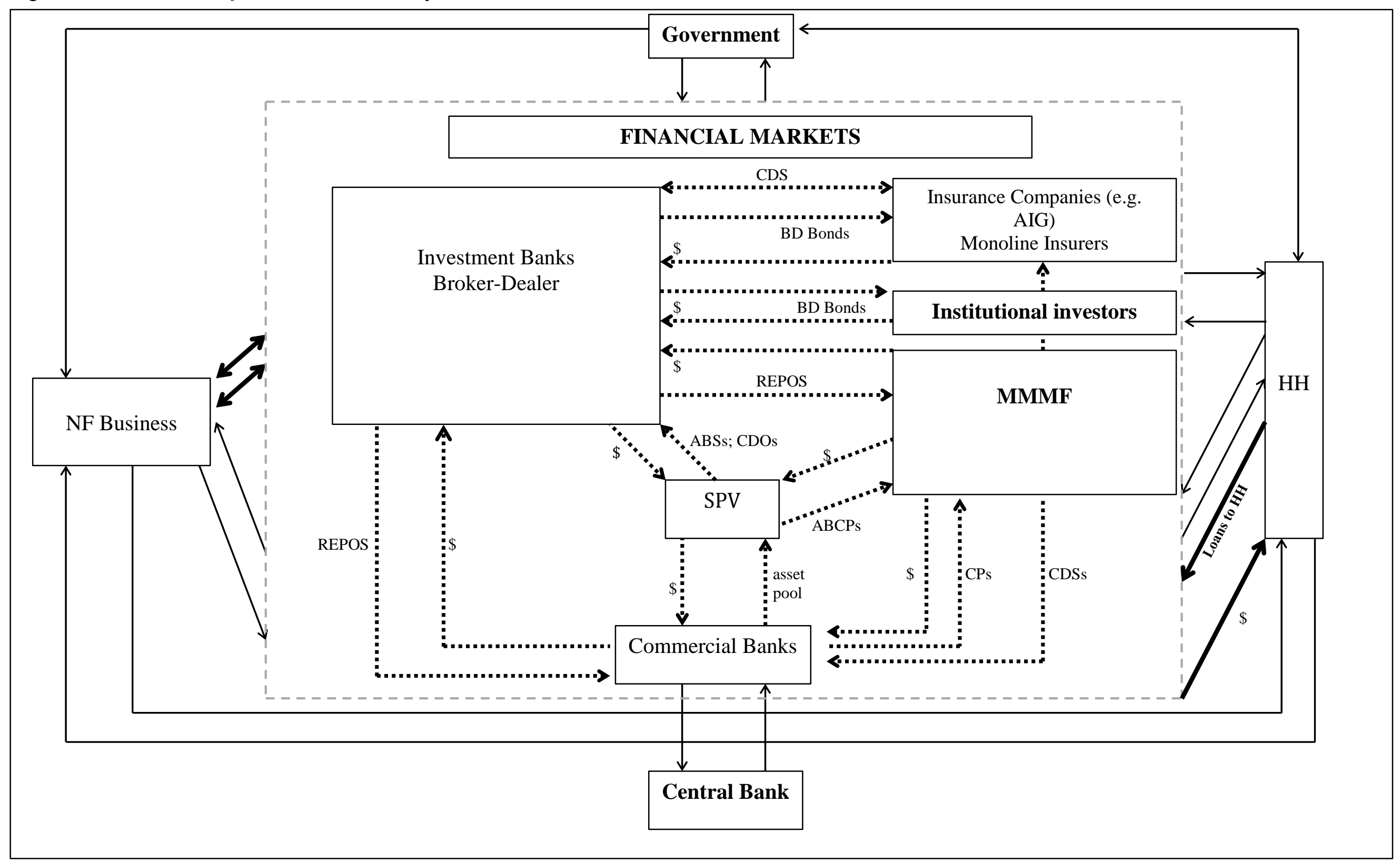




\subsubsection{Financial circuits into matrices}

The balance sheet composition, and the ensuing flow of funds emerging in the financialized monetary circuit drawn in Figure 13 are analyzed more formally in the matrices reported below. Many studies have already attempted to describe the functioning of shadow banking through the mechanisms of stock-flow-consistent matrices (Eatwell, Mouakil and Taylor, 2008; Pilkington, 2008; Lavoie, 2009). Here we follow the same approach but we present a more detailed picture by taking explicitly into account the several actors composing the shadow banking system, as well as some specific asset they use in their operations. We start by presenting matrices $2 \mathrm{a}$ and $2 \mathrm{~b}$, in which we describe in the simplest possible way the very essence of securitization. We end up with the highly complex Matrices 3a and 3b, in which all the financial actors portrayed in Figure 13 are eventually considered. In building Matrices 3a and 3b, we relied on data gathered from the US Flow of Funds, to offer a realistic albeit simplified representation of the balance interconnections underling the private sector of the US economy. ${ }^{13}$

Matrix 2a partially extends the representation of current financial systems already proposed by Eatwell, Moukil and Taylor (2008). Here we explicitly take into account the operation of both SPVs and market-based financial operators. Assets and liabilities connected to securitization are in bold letters. In Matrix 2a, commercial banks provide loans and mortgages to households and nonfinancial firms. However, differently from Matrix 1b, a fraction ' $z$ ' of these assets is securitized and sold to SPVs. SPVs liabilities are represented by ABSs that are purchased by market-based financial operators. Once again, commercial banks lie at the center of the payment system. Households and non-financial firms hold demand deposits in order to store wealth in the most liquid form possible. This is particularly true in the event financial turbulences render demand deposits safer and more appealing assets than long-term ones, such as shares of market-based operators $\left(\mathrm{SH}_{\mathrm{lt}}\right)$. In the case of financial institutions such as SPVs and financial intermediaries, bank deposits play a purely instrumental role. They might be thought of as slightly positive or, for most of the time, close-to-zero liquid holdings in financial operators' balance sheets that allow payment services to be effectively carried out, since they are instrumental to the use of credit money. 
Matrix 2a-Institutions' balance sheets in a simple financialized economy with SPVs and non-bank financial operators.

\begin{tabular}{|l|c|c|c|c|c|c|c|}
\hline & $\mathrm{HH}$ & RENTIERS & FIRMS & BANKS & SPV & MBBANKS & \\
\hline Real Capital & & & $+K$ & & & & $+K$ \\
Loans & & & $-L_{f}$ & $+\boldsymbol{L}(1-z)$ & $+\boldsymbol{L}(z)$ & & 0 \\
Mortgages & $-M$ & & & $+\boldsymbol{M}(1-z)$ & $+\boldsymbol{M}(z)$ & & 0 \\
Deposits & $+D_{h}$ & $+D_{r}$ & $+D_{f}$ & $-D$ & $+D_{s}$ & $+D_{m b}$ & 0 \\
Obligations & & & $-O$ & & & $+O$ & 0 \\
ABS & & & & & $-A B S$ & $+A B S$ & 0 \\
Shares & & $+S H_{b}$ & & & & $-S H_{b}$ & 0 \\
houses & $+p H$ & $+p H$ & & & & & $+p H$ \\
\hline
\end{tabular}

Matrix $2 b$ describes the flow of funds characterizing such an economic system. It thus takes explicitly into account flows of funds that originate from securitized assets, as well as new rounds of securitization.

Matrix $2 b-$ Flow of funds in a simple financialized economy with SPVs and non-bank financial operators.

\begin{tabular}{|c|c|c|c|c|c|c|c|c|c|c|c|c|c|c|}
\hline & \multicolumn{2}{|c|}{$\mathrm{HH}$} & \multicolumn{2}{|c|}{ Rentiers } & \multicolumn{2}{|c|}{ FIRMS } & \multicolumn{2}{|c|}{ BANKS } & \multicolumn{2}{|c|}{ SPV } & \multicolumn{2}{|c|}{ MBB } & \multirow[t]{2}{*}{$\Sigma$} \\
\hline & & Current & Capital & Current & Capital & Current & Capital & Current & Capital & Current & Capital & Current & Capital & \\
\hline Cons. & & $\cdot C_{h}$ & & $-C_{h}$ & & $+C$ & & & & & & & & 0 \\
\hline Inv. & & & & & & $+\Delta K$ & $-\Delta K$ & & & & & & & 0 \\
\hline Wages & & $+W$ & & $+W$ & & $\cdot W$ & & & & & & & & 0 \\
\hline Int. on & $L$ & & & & & $-i L_{f}$ & & $+(1-z) i L_{f}$ & & $+(z) i L_{f}$ & & & & 0 \\
\hline & $M$ & $-i_{b} M$ & & & & & & $+(1-z) i M$ & & $+(z) i M$ & & & & 0 \\
\hline & $D$ & $+i D_{k}$ & & $+i D$ & & $+i D_{f}$ & & $-i D$ & & $+i D_{s}$ & & $+i D_{m}$ & & 0 \\
\hline 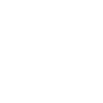 & $\begin{array}{l}O \\
A B \\
S\end{array}$ & & & & & & & & & $-i A B S$ & & $\begin{array}{c}+i O \\
+i A B S\end{array}$ & & $\begin{array}{l}0 \\
0\end{array}$ \\
\hline$\ldots$ & $S H$ & & & $\begin{array}{c}+i S H_{b l} \\
+F b+F m\end{array}$ & & & & & & & & $-i S H_{b}$ & & 0 \\
\hline Divid. & & & & $\begin{array}{c}+F b+F m \\
b\end{array}$ & & & & $-F b$ & & & & $\cdot F_{m b}$ & & 0 \\
\hline Houses & & & $-\Delta p H$ & & $-\triangle p H$ & $+\Delta p H$ & & & & & & & & 0 \\
\hline Totals & & $-S A V$ & $+S A V$ & $-S A V$ & $+S A V$ & $-F$ & $+F$ & 0 & 0 & 0 & 0 & 0 & 0 & 0 \\
\hline Change & $\begin{array}{l}L \\
M\end{array}$ & & $+\Delta M$ & & & & $+\Delta L_{f}$ & & $\begin{array}{l}-(1-z) \Delta L_{f} \\
-(1-z) \Delta M\end{array}$ & & $\begin{array}{l}-(z) \Delta L_{f} \\
-(z) \Delta M\end{array}$ & & & $\begin{array}{l}0 \\
0\end{array}$ \\
\hline & $D$ & & $-\Delta D_{k}$ & & $-\Delta D_{r}$ & & $-\Delta D_{f}$ & & $+\Delta D$ & & $-\Delta D_{x}$ & & $\cdot \Delta D_{m b}$ & 0 \\
\hline & $\begin{array}{l}A B \\
S\end{array}$ & & & & & & & & & & $+\triangle A B S$ & & $-\triangle A B S$ & 0 \\
\hline & $o$ & & & & & & $+\Delta O$ & & & & & & $-\Delta O$ & 0 \\
\hline & $S H$ & & & & $-\Delta S H_{b}$ & & & & & & & & $+\Delta S H_{b}$ & 0 \\
\hline$\Sigma$ & & 0 & 0 & 0 & 0 & 0 & 0 & 0 & 0 & 0 & 0 & 0 & 0 & 0 \\
\hline
\end{tabular}

The main departures with respect to Matrix 1a are reported in bold. These are related to the, let us say, 'accounting effects' of securitization. More in detail, a fraction ' $z$ ' of interest proceeds accruing to commercial banks on originated loans and mortgages is now diverted to SPVs. SPVs, in turn, pay interests to ABS holders. For the sake of simplicity, we assume SPVs not to make profits. All proceeds from held assets are transferred to ABS holders. From the point of view of 
market-based financial operators, interests on ABS holdings constitute an additional source of profits beyond interests gained on non-financial firm bond holdings (iO).

In the bottom part of Matrix 2b we consider new rounds of securitization of newly created loans and mortgages: ( $\mathrm{z}) \Delta L_{f}$ and $(\mathrm{z}) \Delta M$. Accordingly, we also model new ABS issuances by SPVs (i.e. $\triangle A B S$ ). Market-based financial operators may deploy resources recollected from households in order to increase their holding of ABSs. To the eyes of market-based financial operators, ABSs appear as a remunerative investment opportunities alternative to non-financial firms' bonds $(O)$. Accordingly, household savings may no longer flow from households to real-sector firms through financial market intermediation. Savings could remain 'entrapped' in the financial sphere of the economy. Eventually, finance could crowd out non-financial firms, given the higher remuneration and lower perceived risk of ABS.

In Matrices 3a and 3b, we represent the full-fledged financialized monetary circuit portrayed in Figure 13. In Matrix 3a, we first take into account a rentier sector in order to take on board the increasing inequality with which personal income and, in particular, personal wealth is distributed among economic actors. ${ }^{14}$ Households get loans and mortgages from commercial banks. The only assets they hold are liquid demand deposits and houses. On the contrary, on the asset side of the rentiers' balance sheet, we report most of the non-business sector's financial wealth. This takes the form of short-term MMMFs shares (SHst $)_{R}$ or long-term (riskier) investment fund and/or insurance company shares (SHlt). Rentiers also hold demand deposits $D_{r}$. We also assume that real-side firms deploy profits, bank credit or funds recollected on financial markets to purchase finance assets in the form of MMMFs shares.

In Matrix 3a, we disaggregate the market-based financial sector in: money market mutual funds, investment funds, broker and dealers, insurance companies. MMMFs issue short-term liquid assets in order to finance purchases of $A B C P$ s, and provide liquidity to broker and dealers through REPOs. Investment funds may allocate resources to a variety of assets. First, they may still perform their traditional function of conveying recourses towards non-financial firms by purchasing non-financial firm obligations $(O F)$. Second, differently from what implicitly assumed in Matrices $1 \mathrm{~b}$ and 2a, investment funds may also buy obligations issued by investment banks (OFF) or ABSs/CDOs. The propensity of larger investment funds to accumulate inner-finance assets such as ABS and CDOs, the lower the amount of final finance that eventually allows non-financial firms to repay initial bank loans. Last but not least, investment funds may try to make their financial position safer by taking positions on derivative markets and buying CDSs from insurance companies. In Matrix 3a, we do not classify CDSs as assets or as liabilities. Actually, their positive or negative values depend on the occurrence of contingent events (the default of the underlying assets). They will give rise to payment commitments (i.e. premia to insurance companies) or rights to receive payments depending on the prevailing state of the economy. 
Matrix 3a-Institutions' balance sheets in a complex financialized economy with multiple market-based financial operators.

\begin{tabular}{|c|c|c|c|c|c|c|c|c|c|c|}
\hline & $\mathrm{HH}$ & RENTIER & FIRMS & BANKS & SPV & MMMF & INV FUND & $B \& D$ & INS. COMP. & SUM \\
\hline Real Capital & & & $+K$ & & & & & & & $+K$ \\
\hline Loans & $-L_{h}$ & $-L_{r}$ & $-L_{f}$ & $+(1-z) L$ & $+z L$ & & & & & 0 \\
\hline Mortgages & $-M_{h}$ & $-M_{r}$ & & $+(1-z) M$ & $+z M$ & & & & & 0 \\
\hline Deposits & $+D_{h}$ & $+D_{r}$ & $+D_{f}$ & $-D$ & $+D_{s}$ & $+D_{m \mathrm{~m}}$ & $+D_{i j}$ & $+D_{b d}$ & & 0 \\
\hline Obligations firm & & & $-O F$ & & & & $+O F_{i j}$ & $+O F_{d b}$ & $+O F_{i c}$ & 0 \\
\hline Obligations fin. firm & & & & & & & $+O F F_{i j}$ & $-O F F$ & $+O F F_{i c}$ & 0 \\
\hline Money Shares & & $+S H s t_{R}$ & + SHst $_{F}$ & & & $-S H_{s t}$ & & & & 0 \\
\hline Longer Shares & & $+S H l t$ & & & & & SH Hit $t_{F}$ & & $-S H I t_{I C}$ & 0 \\
\hline ABS & & & & & $-A B S$ & $+A B C P$ & $+A B S_{i f}$ & $+A B S_{i f}$ & & 0 \\
\hline REPO & & & & $+R E P O$ & & $+R E P O$ & & $-R E P O$ & & 0 \\
\hline CDS & & & & CDS & & & $\operatorname{CDS}$ & CDS & CDS & 0 \\
\hline houses & $+p H$ & $+p H$ & & & & & & & & $+p H$ \\
\hline
\end{tabular}


Matrix $3 b-$ Flow of funds in a complex financialized economy with multiple market-based financial operators.

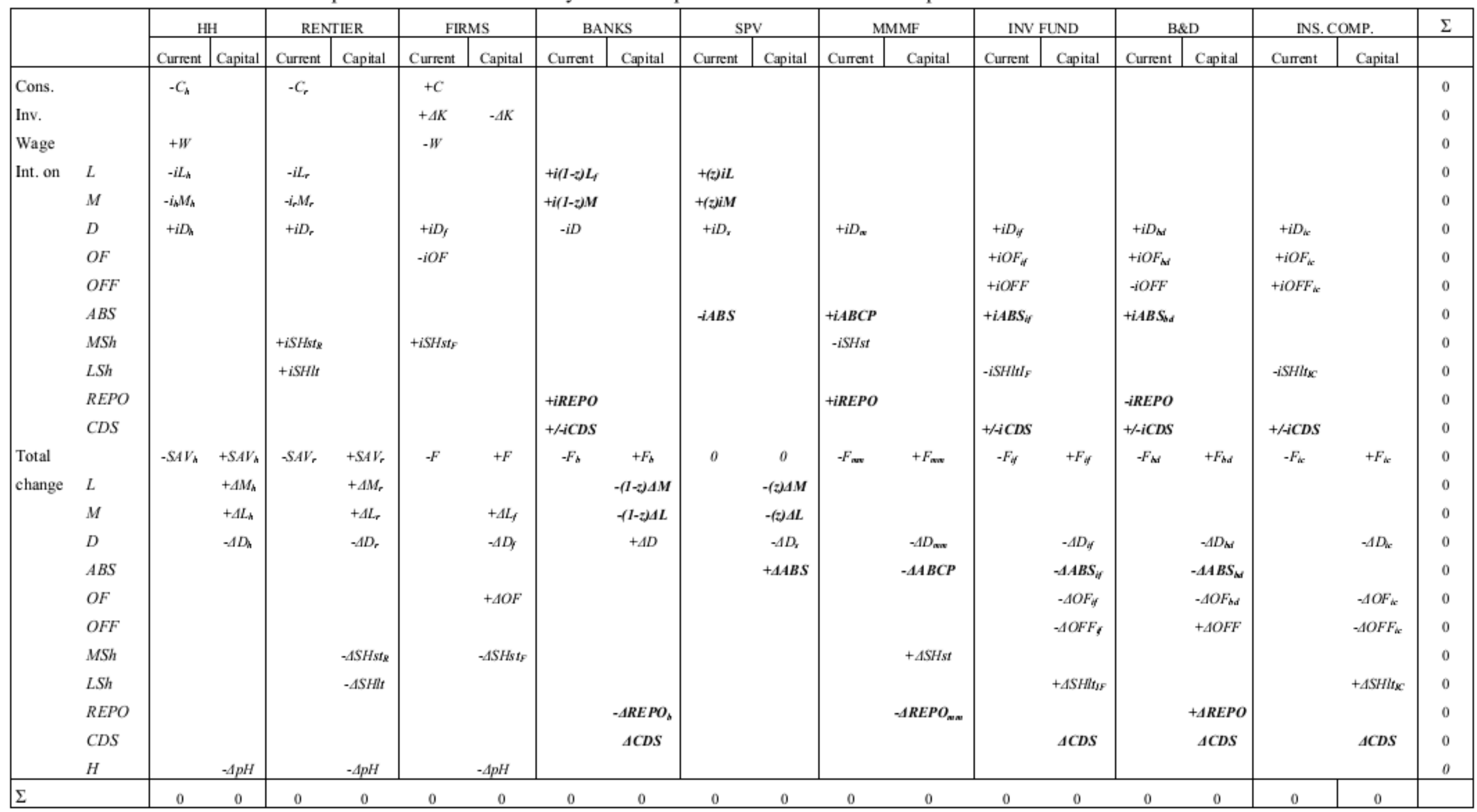


In Matrix 3a, insurance companies can invest in obligations issued by both non-financial firms and investment banks. We assume them not to buy ABSs. Yet, they increasingly take an active part in derivative markets by offering CDS contracts to other financial operators.

Broker and dealers can recollect funds by both issuing obligations (OFF) and/or entering short-term REPO agreements with commercial banks and MMMFs. They will use these resources in order to buy non-financial firms' obligations and/or ABSs. Once again, the latter represents a new and alternative investment opportunity with respect to the traditional investment bank activity of financing long-term real economy projects. Such an alternative becomes even more attractive seeing that investment banks can use ABSs as collaterals in REPO agreements or open new positions on derivative markets. In the end, ABSs holdings may be preferred to the traditional financing of real-side activities because they allow investment banks to quickly expand their business by ballooning their balance sheets.

Matrix 3b reports all the complex network of flow of funds, financial flows in particular (i.e. interest payments/proceeds as well as investment opportunities for the wide set of financial assets available), that emanates from balance sheets included in Matrix 3a. The economic rationale behind matrix $3 \mathrm{~b}$ is equal to the one informing the computation of Matrix $2 \mathrm{~b}$ and does not need further explanations. ${ }^{15}$

\section{Grasping the nature of the financial circuits}

The flow of diagram and the matrices above unveil the internal structure of the financial system, making explicit the interactions that take place within the financial system and between the financial and the real side of the economy. In order to grasp the nature of these relations, their driving forces, and their impact on the economic system, we will revert to the MCT logic. A cornerstone of the circuit is its clear-cut explanation of the central role played by money in the production process of a capitalist economy. Money, when it enters the circuit, is not neutral, as it impacts on relative prices between capital and labour allowing production to take place and then commodities to be exchanged. Money, when it refluxes, leaves someone richer (those who have saved) and someone poorer (those with an increased stock of debt not matched by an increase in assets), may it be units or sectors. A further crucial development of the MCT is the identification of the functional role of each sector. Looking at the financialized economy schematized in the previous sections through these two lenses, i.e. the role of money and the functional role of each sector, MCT may allow us to find a meaningful answer to the above questions.

In our extended monetary circuit, on top of loans to non-financial firms, money may enter the economy through two further channels. The first one corresponds to the debts of the households, i.e. mortgages and loans. The second one consists of the debt of investment banks when they are financed by commercial banks through REPOs. Regardless of the specific origin of these new financial relations, the ensuing debts require a source of final finance to be repaid. We can, therefore, identify two new (sub-) circuits.

The former circuit opens when commercial banks create new deposits by granting new loans $(\Delta L)$ and/or mortgages ( $\Delta M$ ) to households. For the time being, let us assume an aggregated households sector and temporarily neglect the distinction between workers and rentiers. This inflow of money is the new initial finance. If this credit, or a part of it ( $z$, in our matrices), enters the securitization process, an equal amount of money refluxes to commercial banks and is therefore destroyed. Even though the layers of intermediation are numerous, each of the financial operators involved, be it SPVs, MMMFs, investment banks or investment funds, needs to use its 
own deposits to purchase securitized assets or ABSs. No matter the layers of intermediation, nor the amount of time the original credit is pooled and included in sophisticated financial instruments, when a credit enters the securitization circuit, an equal amount of deposits is destroyed. Money unavoidably returns to the issuer of the loans, which is at the same time the seller of the original securitized asset. At this stage of the analysis, it is important to keep in mind that financial operators are intermediaries. Therefore, they need to recollect their clients' (i.e. households) savings to purchase securitized assets and/or derivative products 'constructed' on them (i.e. ABSs). In the end, household deposits, which increased with the initial finance, are the source of money for the circuit to close (the final finance of the original circuit). In this circuit money flows through the economy following three steps. First, money enters through a loan of commercial banks and takes the form of household deposit. Second, households save and use part of this money to purchase assets issued by financial intermediaries, say financial operators' shares $(\triangle S H)$. Correspondingly, financial intermediaries' deposits will increase. Third, financial operators will use their deposits to purchase securitized assets and ABS from commercial banks via SPVs, hence destroying the money.

What emerges from these steps is a key evolution of such a financial circuit, i.e. the commodification of financial relationships. Money, whose role as 'existence condition of [material] production' (Parguez, 2003, p.255) was so clear in the original circuit, gains an additional connotation in this financialized economy. Indeed, money is still needed for production (also of financial system services) and still allows for the transaction. Money is still created through debt, and it is at the same time an asset and a liability. Financial markets now take advantage of this double role, so that the asset counterpart of households' or firms' debt, the initial finance of the circuit, becomes the commodity produced by financial operators and exchanged in financial markets. Parguez's essentiality axiom has never held truer.

Through the mechanisms of this circuit, debt is manipulated and indirectly (through financial operators' shares and securitization) sold by workers of the financial system to households, which in most cases are at the same time the owners of the original liability. However, this situation is far from being a clearing mechanism, the consequences on the economy are numerous, and their effects do not terminate when money returns to the commercial banks.

First, the destruction of money through the passages of securitization creates a deep discontinuity with respect to the outcomes of the traditional monetary circuit. According to the traditional monetary circuit portrayed in Figure 12 and in Matrices $1 \mathrm{a}-1 \mathrm{~b}$, the more commercial banks recollected liquidity through demand deposits, the more banks' money remained in the circuit and the less the circuit closed. A lower amount of initial bank loans were repaid. They remained on the asset side of commercial banks' balance sheets. Accordingly, banks might have been inhibited to further expand their business due to the ensuing increase in leverage and the rise in their financial vulnerability. In Figure 13, securitization now implies that money initially created by commercial banks is eventually destroyed when banks sell the corresponding assets to SPVs. However, money destruction is now decoupled by asset destruction and debt repayment by initial borrowers. Borrowers' initial liabilities are still on, but they do not figure on commercial banks' balance sheets any longer. They are now polled in the balance sheet of other financial operators, and figuratively incorporated in ABSs. From an aggregated perspective, the liquidity in circulation decreases, but the original credit relations and the connected payment commitments continue to exist. While the financial solidity of commercial banks apparently improves, overall macroeconomic solidity certainly does not (see again the Appendix on this point). ${ }^{16}$ 
Second, the set of proceeds left by this circuit, and more in general subtending the relation between the financial and the household sector, is detrimental for the latter. It is well known that banks apply an interest on deposits lower than the one they receive on loans. Furthermore, the securitization of mortgages not only determines the level of liquidity of assets, it also transforms their quality. As described by Pozsar Z. et al. (2013), ABSs and shares of MMMFs are both more liquid and considered more secure than their underlying assets. Since interest rates decrease together with the level of perceived risk, financial engineering has allowed the financial sectors to make profits out of interest differentials. If credit was households' only source of income, it would be obvious that they would unescapably be in a Ponzi position, requiring new credit to repay past financial commitments. The exact same logic applies to the value of assets, which will increase with any step of the securitization process. This price and interest rate differentials determine the profits of the financial system. These profits, in particular those arising from price differentials, immediately raise some difficulties, since they emerge within the circuit. The difference between the price paid by the household sector to purchase financial assets (Sh) and the money used by financial intermediates to buy 'securitized' credit positions from banks, will not be immediately destroyed. It will therefore remain in the economy and will be used according to the decision of the profit earners. Buying further financial assets is only one of the possibilities.

The financial system does not need to use exclusively money collected by selling shares to households. Indeed, we should also think about the kind of inner-finance circuit already sketched in Section 3. It represents the second of our financial circuits. Such an inner-finance circuit takes place when commercial banks stretch liquidity to brokers and dealers through REPOs, which in turn use these funds to purchase ABSs. This is a self-feeding circle. On the one hand, commercial banks indirectly 'produce' and supply ABSs to be sold to investment banks. On the other hand, commercial banks may provide investment banks with the required money to buy ABSs, hence stimulating ABS demand. The apparent endless and explosive nature of this circuit is clear. Securitization figuratively allows commercial banks to act more aggressively on financial markets and thus to provide liquidity to investment banks. Investment banks have access to REPOs by using ABSs as collaterals. Interestingly, within this inside-finance circuit money may be continuously created and destroyed without entering in contact with any real side institutions. This pure inside-finance dynamic may significantly contribute to financial hyperactivity, financial bubbles, and financial asset inflation as theorized by Toporowsky (2000), and described by Cingolani (2013) in the case of the European Union. Needless to say, this cycle strongly relies on financial operators' confidence in ABSs as safe and liquid assets. In the Keynesian jargon, we might say that the abrupt break-up of these conventions in August 2007 turned bulls into bears and led to the complete collapse of financial and credit markets. The above inside-finance circuit dried up.

\subsection{Enriching the picture}

Some more points are worth stressing in order to enrich the description of our financialized monetary circuit. They mostly concern the financial position of households in the era of financialization.

Households get money from commercial banks, directly or indirectly, in a multiplicity of ways. They receive wages from firms, interest income on previously accumulated wealth, new money provided by commercial banks through new loans and mortgages. Households may 
decide to use the money they get from banks in different ways, exerting different impacts on the economy. Let us first assume that households mostly use new inflows of money from commercial banks in order to buy consumption goods in excess of wage income. Hence, it nourishes one of the possible sources through which firms can obtain the final finance they need to close the traditional circuit, namely the proceeds deriving from the sale of the goods produced. This also allows to overcome the difficulties in the identification of the source of profit or interest repayment characterizing the original circuit (Parguez, 2003; Zezza, 2004; Messori and Zazzaro, 2004; Rochon 2005).

On the contrary, in the event that the value of the consumption goods purchased by households does not exceed nominal wage, households will have the chance to repay the loan using their labour income. The new inflow of money, in this case, would only serve to ease the circulation of commodities- anticipating the means of payment - and will exert no impact on the balance sheets of the sectors. Also in the case money is used to purchase the securities of nonfinancial firms, this new money will determine a source of funds for the traditional circuit to close. Nevertheless, the dynamic identified by Graziani (2003, p. 29) according to which 'the money that wage earners spend in the commodities market, as well as money spent in the financial market on the purchase of securities, flows back to the firms' takes place with two key differences. First, the purchasers of commodities are not pure wage earners and might be better labeled as 'indebted consumers' (Bellofiore, 2013). Second, when money is spent to buy securities, money does not flow back to the same sector that received it as the initial financial; it is rather channelled from the households to the non-financial sector, leaving the former indebted (this can be understood as an increase in explotation)

Alternatively, part of households' financial wealth may take the form of commercial bank deposits. If we neglect for a while the effects of increasing household debt on the possibly positive net financial position of the overall non-financial business sector, the more household savings consist of demand deposits, the less non-financial firms (at least part of them!) will repay their own initial debt. In this case, Graziani's perspective still holds true when, in line with Steindl's 'enforced indebtedness' (Steindl, 1952), he identified in money balances (notes or deposits) a barrier for the circuit to close (see Graziani, 2003).

Finally, take into account the case in which households decide to purchase existing dwellings. We all know that real estate purchasing did play a key role in the US economy. The inflow of money, passing though the real estate market, determines the price of the houses, which in many cases are the assets households hold as collateral against mortgage and loan liabilities that do not disappear with the end of the financial circuit, but rather are 'distributed' into financial markets. A peculiarity of our financial circuit is that even though money is eventually destroyed through securitization, the households' debt position is still pending (and unchanged). Such a debt needs to be repaid. If we do not assume that the household sector is able to save - an assumption that will leave the original circuit open, hence only moving the problem - they will need to recurr to new debt to meet their financial needs. This self-reinforcing dynamic relies on the need for continuous access to credit, which in turn depends on the increase in value of the underlying assets used by households to back loans, namely houses. This indebtedness spiral is potentially endless and will continue as long as fuelled by new credit. At the micro level, it becomes sustainable with the selling of the dwelling. Ultimately, thanks to the rising value of houses, the single household unit will be able to meet its financial obligations by selling its house and obtaining the required liquidity to repay its (original or refinanced) debt back. This is the reflux of this financial circuit. Nonetheless, at the macro level, the provision of final finance 
(commodity or securities selling in the original version) now corresponds to the opening of a new circuit, i.e. loans provided to those households who buy houses. This shows the fragility of this system, based on mortgage issuing and overall household debt. It requires an ever-lively demand for dwellings and increasing house prices, as noted by Gorton (2010).

Last but not least, we can distinguish two classes of households, as done in Matrices $2 a / 2 b$ and $3 \mathrm{a} / 3 \mathrm{~b}$. On the one hand, workers live exclusively out of their wage income and get indebted towards banks. On the other hand, rentiers also receive interest income from the ownership of financial assets (in our example distributed profits and interests on shares), on top of usually higher wages. This assumption can hardly be considered as unrealistic, since that income inequality is a well-established stylized fact (see Piketty, 2014) which, according to several authors, has played a key role on the way towards the subprime crisis which has recently shattered the financialized economies depicted in this paper (Van Treeck, 2013). In practice, we deal with a class of rentiers that extrapolates wealth from the financial circuit, whilst the other class, workers, needs access to credit to sustain a process in which they are at best a channel through which money, which springs from commercial banks flows to rentiers. In canalizing money, workers are allowed a certain level of well-being since they can consume and have a house. However, this well-being is ultimately transitory and does not transform into (permanent) wealth since the dwelling will need to be sold to keep the scheme working.

\section{Conclusions}

In the last decades, the financial system experienced a terrific growth, whose impact on the real side of the economy has been the object of several studies. However, the financial system has mostly been treated as an aggregated homogeneous entity, or alternatively described from a micro perspective without paying attention to the macroeconomic implications of new microlevel strategies. This paper tries to lift the veil over the financial side of the economy in order to portray in more detail its inner dynamics and include them in a macroeconomic framework. In order to reach this goal, we rely on the monetary circuit theory (MCT). The MCT, originally focusing on the role of bank money in allowing production processes to take place, is highly informative if applied to an insightful representation of the balance sheet interconnections underlying the dynamics of finance, both inside the financial system itself and with respect to the real side of the economy. Alongside a schematic representation of the financial system, we identify two new circuits in which the creation of money is detached by standard production processes. These circuits appear as highly unstable since they require a continuous influx of money (i.e. new debt). In our analysis, instability eventually appears to be the major problem for the economy as a whole arising from the aforementioned financial dynamics.

Under a circuitist perspective in which money is endogenous, we do not find an immediate negative impact of the financialized circuits on economic growth. In particular, there is no automatic crowding out effect of productive investment in favor of financial speculation. Nonetheless, these new circuits, as well as the practice of commodification of credit around which they evolve, are potentially very harmful for the economy. The high demand of financial assets, in particular securitized debt, from brokers and dealers and investment funds, pushed the banking sector to issue credit and to sell it - once securitized - through the SPV. This demand-led dynamic stimulated the production of financial assets and had its counterpart in the increasing indebtedness of the household sector and the increasing fragility of the economy as a whole. This is linked to the second real-side problem arising from the financial circuits. The securitization of 
credit feeds income inequality. The indebtedness of workers is functional to the financial returns of rentiers. This is a self-reinforcing dynamic, inherent to the balance sheets of the two households sectors. Commodified financial instruments channel financial resources from the sector holding a liability to the sector holding the correspondent assets. The net position of debtor and creditor, respectively of households and rentiers vis à vis the financial markets, determines a continuous flux of money from the former to the latter.

A final intriguing result of our paper refers to the concept of financialization, whose definition is often unclear and non univocal. In a monetary theory of production, financialization can be conceived, and could be defined, as a shift of the main channel of money creation from real production to financial speculation.

This paper sheds light on the financial system from a specific perspective, the one of the financial circuit. Not surprisingly, significant parts of the issue remain nebulous and would need further investigation. In particular, we plan with future works to deepen our analysis on the role of central banks and income distribution.

\section{Notes}

1 The SFC literature (see Godley and Lavoie, 2007; Caverzasi and Godin, 2014) largely benefited from the theoretical framework developed by the monetary circuit theory in its attempt to describe the functioning of a monetary economy of production, explicitly taking into account the financial aspects linked with real-side dynamics. The SFC approach shares with the MCT the focus on tracking flux and reflux of financial resources among the different sectors of the economy and expands it to the accumulation of different types of real and financial stocks. For a deeper analysis on the close relationships between these two strands of analysis, see Lavoie (2004).

${ }^{2}$ In a way, we try to enter much more into the details of what Cingolani (2013) labels as a "double monetary circuit of existing and recycled savings (Cingolani, 2013, p. 2)” that helps explaining financialization and asset capital inflation.

${ }^{3}$ For a comparison in size and composition with the financial sectors of the Euro Area and Japan, see Bank of Japan (2015).

${ }^{4}$ In this paper, for the sake of simplicity, we will use the expressions 'investment banks' and 'broker and dealers' as synonymous.

5 The GSE are financial corporations built by the US government to ensure flow of finance to key sectors, as the housing market and the agricultural sector.

${ }^{6}$ In a chartalist approach, also government initially finances its expenditures through new liquidity stretched by banks.

${ }^{7}$ For the sake of simplicity, here we do not distinguish between bond holdings or equity holding as different investment instruments and alternative investment opportunities from the point of view of final savers.

${ }^{8}$ Following Gorton (2010), and Gorton and Metrick (2010), there are at least two good reasons that made ABSs appear as liquid, attractive, and information-insensitive investment options to a vast series of financial operators. First, pooling and tranching techniques characterizing securitization make ABSs seemingly riskless assets. Second, when commercial banks' assets are moved off their own balance sheet into SPVs balance sheets, they get bankruptcy-remote to direct creditors of the originating banks. Direct creditors of commercial banks cannot advance any claim on these assets in the event that the originating banks will fail. The high safety degree of SPVs assets is in turn translated into the allegedly high safety level of the corresponding liabilities since those purchasers of SPVissued ABSs will support relatively low creditors' risks. MMMFs demanded large quantities of short-term ABCPs as remunerative and secure assets. Investment banks purchased increasing amounts of ABSs to be used as collaterals in REPO agreements and derivative contracts. The expanding supply of ABSs was functional to ballooning brokers' and dealers' economic activity.

${ }^{9}$ See Pozsar et al. (2013) on the complexity of securitization practices and the functioning of shadow banking.

${ }^{10}$ See the Appendix for a simple illustrative numerical example on these mechanisms.

${ }^{11}$ MMMFs perceived REPOs as profitable substitutes for liquid demand deposits due to the guarantees provided by allegedly riskless ABSs (rather than federal deposit insurances) used as collaterals in REPO contracts.

12 The self-feeding nature of such an inner-finance cycle appears even clearer if one thinks that REPOs are collateralized by ABSs.

${ }^{13}$ Arguably the heaviest simplification is the exclusion of equities, which, as shown in Figure 3 (Section 2), have significantly increased their role in the financial markets since the 80s. The functional role of equities in or analysis is captured by the obligations of non-financial firms.

14 See Goda and Lysandrou (2014), and Lysandrou and Nesvetailova (2014) on the role of wealth concentration in feeding the demand for ABSs and CDOs. 
15 In Matrix 3b, payment flows associated to CDSs are reported with both a positive and negative sign. Indeed, CDSs give rise to payable or receivable amounts according to the contingent state of the underlying asset. The 2007 financial shock has abruptly transformed insurance companies' receivables into huge payable amounts, this way shattering the solidity of the whole financial system.

16 Also in the traditional circuit, as presented by Graziani (2003), initial money may be destroyed without necessarily implying a corresponding reduction in someone else debt, when final finance is provided to original borrowers through financial markets' intermediations. Still, this transformation helps initial borrowers to make their financial positions more reliable as final obligations take the form of equities. Such a transformation does not happen any longer through securitization. Liquidity is destroyed, but the only change is simply in the explicit or implicit ownership of these very same credits.

\section{References}

Adrian T., and A.B. Ashcraft. 2012. Shadow banking: A review of the literature, Federal Reserve Bank of New York Staff Report Paper n. 580.

Adrian T., and H.S. Shin. 2010. The changing nature of financial intermediation and the financial crisis of 2007-2009, Federal Reserve Bank of New York Staff Report n. 439.

Aglietta, M. 2000. Shareholder value and corporate governance: some tricky questions, Economy and Society, vol. 29 (1):146 - 159.

Bank of Japan. 2015. Flow of Funds - Overview of Japan, US, and the Euro area - July 2 Research and Statistics Department. https://www.boj.or.jp/en/statistics/sj/sjhiq.pdf

Beck T., Degryse H., and C. Kneer. 2014. Is more finance better? Disentangling intermediation and the size effects of financial systems, Journal of Financial Stability, vol. 10: 50 - 64.

Bellofiore, R. 2013. Two or three things I know about her: Europe in the global crisis and heterodox economics, Cambridge Journal of Economics, vol.37 (3):497-512.

IMF. 2015. Interview with Olivier Blanchard. Blanchard: Looking Forward, Looking Back. IMF Survey Magazine: IMF Research. Full text at http://www.imf.org/external/pubs/ft/survey/so/2015/RES083115A.htm

Boyer, R. 2000. Is a finance-led growth regime a viable alternative to Fordism? A preliminary analysis, Economy and society, vol. 29 (1):111 - 145.

Caverzasi, E., and A. Godin. 2015. Post-Keynesian stock-flow-consistent modeling: a survey, Cambridge Journal of Economics, vol. 39 (1):157 - 187.

Cecchetti, S.G., and E. Kharroubi. 2012. Reassessing the impact of finance on growth, BIS Working Paper n.381.

Cingolani, M. 2013. Finance capitalism: A look at the European financial accounts, Panoeconomicus, vol. 60 (3):249 - 290.

Crotty, J. 2005. The neoliberal: The impact of destructive market competition and modern financial markets on nonfinancial corporations performance in the neoliberal era, in: Epstein G. (ed.) - Financialization and the world economy, Cheltenham (UK): Edward Elgar.

Demir, F. 2009. Financial liberalization, private investment and portfolio choice: financialization of real sectors in emerging markets, Journal of Development Economics, vol.88 (2):314 324.

Eatwell, J., Mouakil, T., and L. Taylor. 2008. Liquidity, leverage and the impact of sub-prime turbulence, Centre for Financial Analysis and Policy, Judge Business School, University of Cambridge.

FED. 2015. Description of table L.130 - Funding Corporations, date $20^{\text {th }}$ of February 2015, (available at http://www.federalreserve.gov/apps/fof/TableDesc.aspx?t=L.130). 
Fumagalli, A., and S. Lucarelli. 2011. A financialized monetary economy of production, International Journal of Political Economy, vol. 40 (1):pp. 48 - 68.

Goda, T., and P. Lysandrou. 2014. The contribution of wealth concentration to the subprime crisis: A quantitative estimation, Cambridge Journal of Economics, vol. 38 (2):301 - 327.

Gorton, G. 2010. Slapped by the invisible hand. The panic of 2007, New York: Oxford University Press.

Gorton, G., and G. Pennacchi. 1995. Banks and loan sales: marketing nonmarketable assets, Journal of monetary economics, vol.35 (3):389 - 411.

Gorton, G., and A. Metrick. 2009. Securitized banking and the run on Repo, NBER Working Paper n. 15233.

Gorton, G., and A. Metrick. 2010. Regulating the shadow banking system, Brookings Papers on Economic Activity, fall 2010:261 - 312.

Graziani, A. 2003. The Monetary Theory of Production. Cambridge, UK: Cambridge University Press.

Hein, E. 2011. Financialization, distribution and growth, in: Hein E. and Stockhammer E. (eds) A modern guide to Keynesian macroeconomics and economic policies, pp. 294 - 324, Cheltenham: Edward Elgar.

Kane, E. 2013. The inevitability of shadowy banking, INET research note n. 25, freely downloadable from the website: http://ineteconomics.org/grants/papers/inevitabilityshadowy-banking.

Lavoie, M. 2004. Circuit and coherent stock-flow accounting, in: Arena R. and Salvadori N. (eds.), Money, Credit, and the Role of the State: Essays in Honour of Augusto Graziani. Aldershot, pp. 134 - 149, UK: Ashgate.

Lavoie, M. 2009. Towards a post-Keynesian consensus in macroeconomics: Reconciling the Cambridge and the Wall Street view, in: Eckhard E., Torsten N. and Stockhammer E. (eds.) Macroeconomic Policies on Shaky Foundations - Whither Mainstream Economics?, Berlin: Metropolis.

Law, S.H., and N. Singh. 2014. Does too much finance harm economic growth?, Journal of Banking \& Finance, vol.41 (1):36 - 44.

Lysandrou, P. 2013. Financialization and the limits of the circuit theory, paper available for download from http://www.postkeynesian.net/downloads/soas14/PL300514.pdf.

Lysandrou, P., and S. Nesvetailova. 2014. The role of shadow banking in the financial crisis: a disaggregated view, Review of International Political Economy, published online march 2014.

Messori, M., and A. Zazzaro. 2004. Monetary Profits within the Circuit: Ponzi Finance or “Mors Tua, Vita Mea”?, Working Paper n.200, Department of Economics, Marche Polytechnic University.

Orhangazi, O. 2008. Financialization and the US Economy, Northampton, MA (USA): Edward Elgar.

Orhangazi, O. 2011. Financial vs real. An overview of the contradictory role of finance, PERI Working Paper n. 274.

Parguez, A. 2003. The Solution of the Paradox of Profits, in Arena R. and N. Salvadori (eds) Money Credit and the Role of the State - Essays in honour of Augusto Graziani. Ashgate.

Parlour, C., and G. Plantin. 2008. Loan sales and relationship banking, Journal of finance, vol.63 (3): $1291-1314$.

Passarella, M. 2014. Financialization and the monetary circuit. A macro-accounting approach, Review of Political Economy, vol. 26 (1):128 - 148. 
Passarella, M., and M. Sawyer. 2013. Financialization in the circuit, FESSUD Working Paper n. 18.

Piketty, T. 2014. Capital in the 21th Century, Harvard University Press.

Pilkington, M. 2008. Conceptualizing the shadow banking system in a stock-flow-consistent accounting framework, Global Business and Economics Anthology, vol. 2:268 - 279.

Pozsar, Z., Adrian, T., Ashcraft, A. and H. Boesky. 2013. Shadow banking, FRBNY Economic Policy Review, vol. 19 (2):1 - 16.

Rochon, LP. 2005. The existence of monetary profits within the monetary circuit, The existence of monetary profits within the monetary circuit, in Fontana G. and R. Realfonzo (eds.) - The Monetary Theory of Production. Tradition and Perspectives, New York: Palgrave Macmillan.

Seccareccia, M. 2013. Financialization and the transformation of commercial banking: understanding the recent Canadian experience before and during the international financial crisis, Journal of post-Keynesian Economics, vol. 35 (2):277 - 300.

Stein, J. 2010. Securitization, shadow banking and financial fragility, Daedalus, vol. 139 (4):41 $-51$.

Steindl, J. 1952. Maturity and Stagnation in American Capitalism. Oxford Institute of Statistics Monograph n.4, Oxford: Basil Blackwell.

Stockhammer, E. 2004. Financialization and the slowdown of accumulation, Cambridge Journal of Economics, vol.139 (4):41 - 51.

Toporowsky, J. 2000. The end of finance: Capital market inflation, financial derivatives and pension fund capitalism, London: Routledge.

Van Treeck, T. 2008. Reconsidering the investment-profit nexus in finance-led economies: an ARDL-based approach, Metroeconomica, vol. 59 (3):371 - 404.

Van Treeck, T. 2013. Did Inequality Cause the U.S. Financial Crisis? Journal of Economic Surveys, vol.28 (3):421-448.

Zezza, G. 2004. Some simple, consistent models of the monetary circuit, Levy Economics Institute working paper n.405.

Wray, R. 2007. Lessons from the subprime crisis, Levy Economics institute Working Paper n.522. 


\section{APPENDIX}

Let us assume a simple economy in which there are five actors: households $(\mathrm{HH})$, rentiers, Money Market Mutual Funds (MMMF), Special Purpose Vehicles (SPV), and commercial banks. For the sake of simplicity, we do not consider production. We focus on the distribution of assets and liabilities among actors, and the way through which assets may be transferred from one to the other. Five assets are initially assumed to exist: mortgages (M), demand deposits (D), banks' reserves (R), banks' equities (PE), houses (PH). Two additional assets are introduced later on when securitization and inside-finance transactions are taken into account: MMMFs' shares (Sh) and asset-backed securities (ABS). Matrix A1 below provides a hypothetical numerical configuration of such an economy.

Matrix A1 - securitization and flexibility of commercial banks' balance sheet. A numerical example.

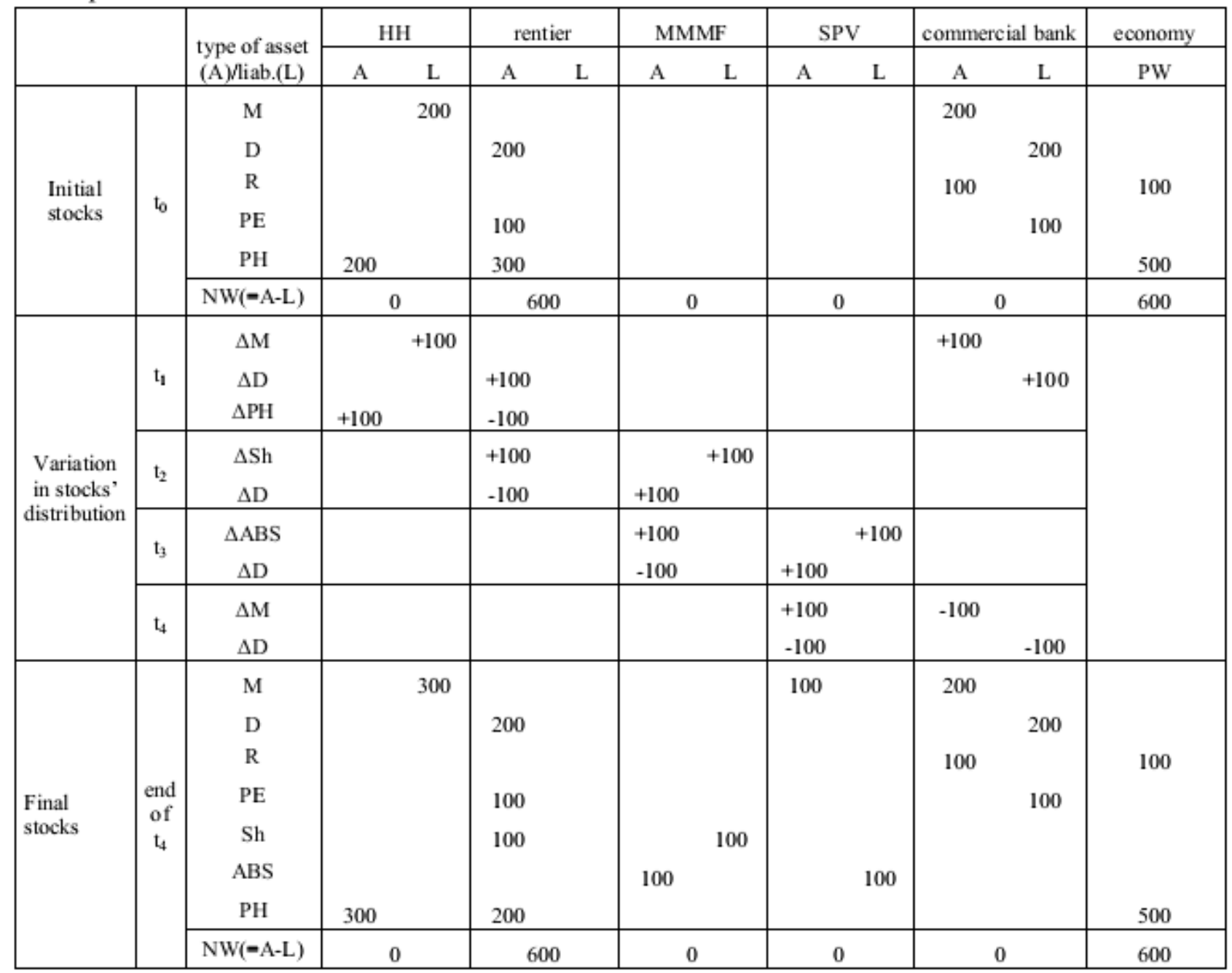

Let us assume that at the end of time $t_{0}$ households own houses whose value is 200\$. In order to buy houses from rentiers, they have previously got indebted with banks for the same amount. Such a financial relationship appears on the liability side of household balance sheets and on the asset side of commercial bank balance sheets. Financial resources obtained from banks have been subsequently moved to rentiers, who in turn deposited them on their own bank account. Rentiers also own houses for $300 \$$, as well as equities originally issued by banks whose value is $100 \$$. Total rentiers' original or primary wealth amounts to $600 \$$. We assume initial commercial 
banks' provision by equity issuing to be stored in the form of reserves. MMMFs and SPV do not play any role on the onset.

Now assume that at time $t_{1}$, households buy additional houses from rentiers for an amount equal to $100 \$$. In order to do so, they get additional loans from banks for the same amount. After this transaction is completed, $100 \$$ more are credited on rentiers' bank deposits. Should the traditional 'originate and hold' practice still prevail, changes in the creation of financial relationships and in the distribution of assets would stop here. Banks would have observed a $100 \$$ increase in their asset value. Correspondingly, bank liabilities in the form of demand deposits would have increased by the same amount. Thus, the economic activity of banks would have expanded. Nevertheless, given the initial financial provision from rentiers (100\$), banks' leverage would have increased as well, and the banks' financial solidity weakened.

The move from 'originate and hold' practices to securitization implies three new phases and financial relationships to emerge. At time $t_{2}$, we assume that rentiers exchange bank deposits for MMMFs shares. Rentiers' deposits decrease by $100 \$$ whilst rentiers now hold $100 \$$ more in the form of MMMFs shares. MMMFs are credited with $100 \$$ banks deposits while issuing liabilities for the same amount. From an aggregated perspective, nothing changes from the point of view of commercial banks (there has only been a change in the ownership of banks deposits). At time $t_{3}$, SPVs issue ABSs. MMMFs buy $100 \$$ value ABSs by transferring $100 \$$ on SPVs' bank account. The final step of securitization takes place at time $t_{4}$ when commercial banks sell $100 \$$ value assets to SPVs that in turn pay asset purchases by extinguishing their own bank deposit. At the end of time $t_{4}$, bank assets are thus moved off their balance sheet and passed into SPVs balance sheets. Through this passage, even though bank money created at time $t_{1}$ is destroyed, the corresponding assets are still around in the economy. From an aggregated point of view, whilst new financial assets have been created by commercial banks and allocated somewhere in the economic system, commercial banks retain larger margins of maneuver to further expand their business. On the one hand, their profitability is increased, since they still earn fees for servicing payments commitments linked to securitized assets (this transaction is not reported in matrix A1). On the other hand, commercial bank leverage is not changed at all from $t_{0}$ to $t_{4}$. It is even lower than financial exposure theoretically emerging from a traditional 'originate and hold' practice (see step $t_{1}$ ). It goes without saying that commercial banks can now operate more aggressively on financial markets, and give rise to a new round of 'originate and distribute'. 